\title{
MASINGAR, a global tropospheric aerosol chemical transport model coupled with
}

\section{MRI/JMA98 GCM : Model description}

\author{
By
}

\author{
Taichu Y. Tanaka*, Kohtaro Orito*, Tsuyoshi T. Sekiyama, Kiyotaka Shibata, Masaru Chiba \\ Meteorological Research Institute, Tsukuba, Japan
}

and

\author{
Hiroshi Tanaka
}

Graduate School of Environmental Studies, Nagoya University, Nagoya, Japan

(Received October 18, 2002 ; Revised January 8, 2003)

\begin{abstract}
This paper presents the first description of a new three-dimensional aerosol chemical transport model, called the Model of Aerosol Species IN the Global AtmospheRe (MASINGAR), which has been developed to study the distributions of atmospheric aerosols and related trace species. MASINGAR is an on-line chemical transport model (CTM) coupled with the MRI/JMA98 GCM. MASINGAR includes nss-sulfate, carbonaceous, mineral dust, and sea-salt aerosols, and accounts for advective transport, subgrid-scale eddy diffusive and convective transport, surface emission, and dry/wet depositions, as well as chemical reactions. The advective transport is calculated using the semi-Lagrangian transport scheme. Parameterization of convective transport is based on the convective mass flux derived by the Arakawa-Schubert scheme. The space and time resolutions of the model are variable, with a standard spatial resolution of $\mathrm{T} 42\left(2.8^{\circ} \times 2.8^{\circ}\right)$ and 30 vertical layers (up to $0.8 \mathrm{hPa}$ ) with a 20 -minute time step. In addition, the model has a built-in, four-dimensional data assimilation (FDDA) system with a nudging scheme incorporating an assimilated meteorological field, which enables the model to realistically simulate a specific period and a short-period forecast of aerosols. The model simulation of mineral dust aerosol in April 2002 suggests that MASINGAR simulates the synoptic scale aerosol events.
\end{abstract}

\section{Introduction}

Atmospheric aerosols have several important effects on the Earth's environment and climate. Not only do they cause regional environmental air pollution and affect human health, they also affect the Earth's radiative budgets directly by scattering and absorbing radiation, and indirectly through changing the optical properties of the clouds by acting as

* Staff Technologist of Priority Research.

(C) 2003 by the Meteorological Research Institute cloud condensation nuclei (CCN) (Twomey, 1974; Charlson et al., 1991 ; Charlson et al., 1992). Unlike greenhouse gases, climatic impacts of aerosol species are still highly uncertain (Intergovermental Panel on Climate Change (IPCC), 2001), because of the inhomogeneous nature of aerosols. The short lifetime, complex chemical compositions, and size distributions of aerosol particles make it difficult to quantitatively evaluate the distributions and radiative effects of aerosols. It is important to understand the atmospheric aerosols for predicting the course of the climate change.

A quantitative evaluation of the climatic 
impacts of atmospheric aerosols is necessary to predict global climatic change. A high-quality global chemical transport model (CTM) is required to quantitatively evaluate the controlling processes and budgets of the trace constituents in the atmosphere. A number of CTMs have been developed by several researchers to investigate the behavior of a variety of chemical species (e.g., Prather et al., 1987 ; Zimmermann, 1987 ; Feichter et al., 1996; Muller and Brasseur, 1995; Brasseur et al., 1998; Takemura et al., 2000; Bey et al., 2001). The CTMs run either "off-line" or "on-line," and both configurations have their advantages and disadvantages. The off-line models use periodically stored historical data from pre-calculated GCM outputs or assimilated meteorological fields to drive atmospheric transport. An off-line CTM allows simulations of specific years and is suitable for evaluations with available observations, often at relatively low computational cost. However, it cannot account for the atmospheric variability within the historical data period (typically, 3 to 12 hours), nor can it evaluate coupling processes between chemistry and the climate. An on-line CTM is integrated into a GCM, and both CTM and GCM are integrated simultaneously. It is often computationally expensive, and may be affected by the climatic biases in the base GCM. However, an on-line CTM is required to study the interactions between chemical species and climate. Also, an on-line CTM can treat the subgrid scale parameterizations in an integrated manner with the GCM, and can account for much finer atmospheric variability than off-line models.

We are developing a new on-line chemical transport model, called the Model of Aerosol Species IN the Global AtmospheRe (MASINGAR), to investigate and assess the global distribution of aerosol species and their impacts on the climate. MASINGAR includes four major aerosol species (nss-sulfate, carbonaceous, mineral dust, and sea -salt aerosols) and consists of advective, diffusive, and convective transport; emissions; wet and dry depositions; and chemical reactions. MASINGAR is coupled with a highly computationally efficient general circulation model, MRI/JMA98 GCM (Shibata et al., 1999), which enables simulations of many chemical compounds at a high resolution within an acceptable computational cost. In addition, we have developed a four-dimensional data assimilation (FDDA) system incorporating a nudging scheme with an assimilated meteorological field, which enables the model to perform a realistic simulation on a specific period, and short-period forecast of aerosols. This paper seeks to describe MASINGAR. In section 2, we describe the structure of MASINGAR. Section 3 presents the treatment of emissions and chemical reactions of aerosols species included in the model. Section 4 gives some brief results obtained from the model.

\section{Model Description}

\subsection{Model Structure}

MASINGAR is an on-line chemical transport model for tropospheric aerosol species and is coupled with an atmospheric general circulation model and a four-dimensional data assimilation system. Figure 1 schematically illustrates the model.

The atmospheric part of the model is a spectral

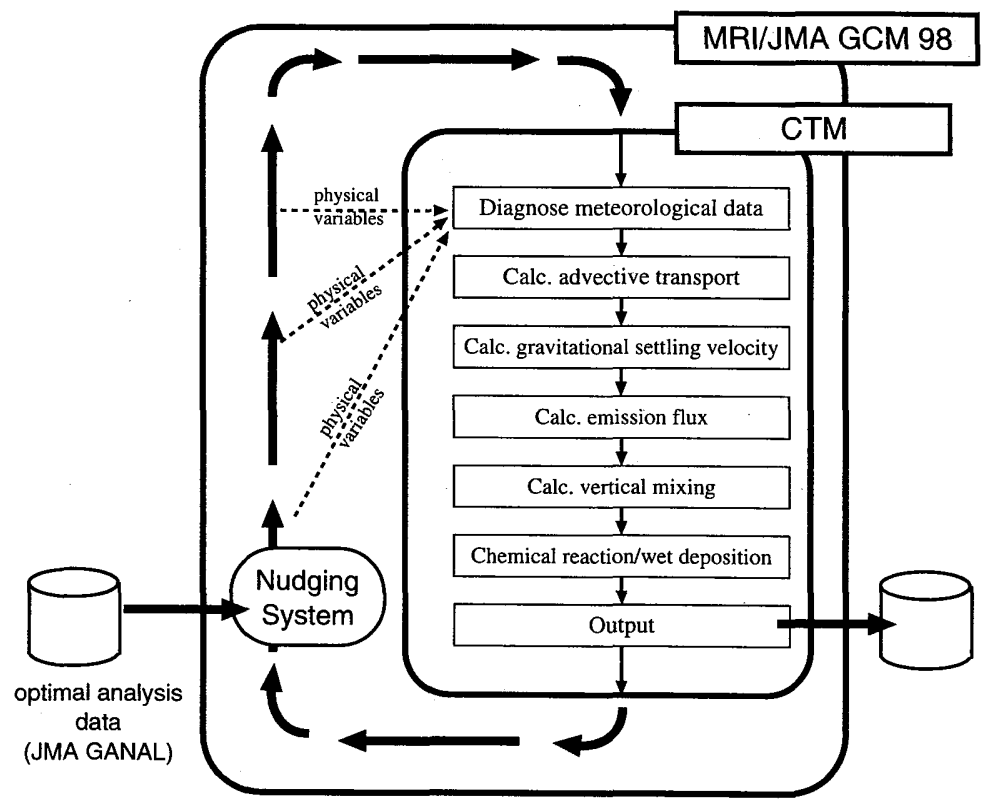

Figure 1. Schematic illustration of the structure of MASINGAR. 
atmospheric GCM, MRI/JMA98 (MJ98) GCM, developed by the Meteorological Research Institute (MRI) and the Japan Meteorological Agency (JMA), based on the JMA global weather forecasting model. Because the GCM has been developed based on a version of an operational weather forecasting model of the Japan Meteorological Agency (JMA), it is designed with high computational efficience. Several physical processes are modified from those of the original JMA version. Details of the MJ98 GCM and its climatic properties are described by Shibata et al. (1999) and references therein.

MASINGAR can be operated at several horizontal, vertical, and temporal resolutions, and the horizontal grid of the CTM coincides to that of MJ98 GCM. Currently, we are mainly developing a horizontal resolution of $\mathrm{T} 21$ and T42, with 30 vertical layers in the hybrid $\rho$-pressure coordinate. With the hybrid $\rho$-pressure coordinate a pressure at a certain level is given by $p=p_{A}+p_{B} p_{s}$, where $p_{s}$ is the surface pressure. Table 1 lists the values of $p_{A}$ and $p_{B}$ for the boundaries of the model layers. The standard time resolution of the calculation of chemical species is 20 minutes for T42 resolution.

Each of the trace constituents is governed by the continuity equation, which includes advective, convective and diffusive transports, together with emissions, wet and dry depositions, and gas- and aqueous-phase chemical reactions. The continuity equation is solved by the operator-splitting technique. Given the volume mixing ratio of $\mathrm{i}-$ th chemical component $\mu_{i}\left(t_{n}\right)$, the equation is solved by successively applying operators to $\mu_{i}\left(t_{n}\right)$ at a time step $n$,

$$
\mu_{i}\left(t_{n+1}\right)=A \cdot D \cdot C \cdot T \cdot \mu_{i}\left(t_{n}\right)
$$

where $A, D, C$, and $T$ are the operators associated with the advective transport, eddy diffusion, convective transport, transformation due to chemical reactions.

Considerable attention was paid to separate the specie-specific program codes from specie-independent codes, so that the model can be compiled either with only one aerosol specie, or multiple aerosol species, and it can be easily extended to other trace species.

\subsection{Data Assimilation}

In order to conduct realistic simulations, we have developed an integrated four-dimensional data assimilation (FDDA) system. The dynamical variables are assimilated with the nudging scheme, which adds tendency at each time step by the form of Newtonian relaxation forcing,
Table 1. Coefficients $\mathrm{pA}$ and $\mathrm{pB}$ for the vertical coordinate of the model (for configuration with 30 layers)

\begin{tabular}{rrlr}
\hline & $p_{A}$ & $p_{B}$ & $\begin{array}{r}\text { Approximate } \\
\text { pressure }[\mathrm{hPa}]\end{array}$ \\
\hline 1 & 0.0 & 1.00000 & 1013.0 \\
2 & 0.0 & 0.99000 & 1002.8 \\
3 & 0.0 & 0.97000 & 982.6 \\
4 & 0.0 & 0.94000 & 952.2 \\
5 & 2.0 & 0.89800 & 911.6 \\
6 & 8.08049 & 0.84203 & 861.0 \\
7 & 19.37306 & 0.77135 & 800.7 \\
8 & 35.68988 & 0.68704 & 731.6 \\
9 & 55.60886 & 0.59202 & 655.3 \\
10 & 76.83899 & 0.49078 & 573.9 \\
11 & 96.71825 & 0.38875 & 490.5 \\
12 & 112.72444 & 0.29164 & 408.1 \\
13 & 122.90710 & 0.20471 & 330.2 \\
14 & 126.17645 & 0.13206 & 259.9 \\
15 & 122.41330 & 0.07613 & 199.5 \\
16 & 112.39163 & 0.03736 & 150.2 \\
17 & 97.53352 & 0.01417 & 111.8 \\
18 & 79.54385 & 0.00320 & 82.7 \\
19 & 61.29939 & 0.0 & 61.2 \\
20 & 45.41002 & 0.0 & 45.4 \\
21 & 33.63931 & 0.0 & 33.6 \\
22 & 24.91968 & 0.0 & 24.9 \\
23 & 18.46027 & 0.0 & 18.4 \\
24 & 13.67519 & 0.0 & 13.6 \\
25 & 10.13046 & 0.0 & 10.1 \\
26 & 7.00256 & 0.0 & 7.0 \\
27 & 4.51665 & 0.0 & 4.5 \\
28 & 2.71837 & 0.0 & 2.7 \\
29 & 1.52663 & 0.0 & 1.5 \\
30 & 0.80000 & 0.0 & 0.8 \\
\hline & & &
\end{tabular}

$\left(\frac{\partial x}{\partial t}\right)_{\text {nudging }}=-\frac{x-x_{\text {analysis }}}{\tau}$

where $x$ is a dynamical variable, $x_{\text {analysis }}$ is an observed dynamical variable from an optimal analysis, and $\tau$ is the time scale of the relaxation. The tendency implied by equation (2) is applied above $850 \mathrm{hPa}$ because the coarse vertical grid of the optimal analysis data may destroy the structure of the planetary boundary layer of the model. Currently, horizontal wind components, air temperature, and (optionally) specific humidity are subject to the assimilation. The default value for the nudging time scale $\tau$ is 24 hours, which is determined from a sensitivity study. The system primarily uses optimal global analysis data produced by JMA (GANAL), but it can use assimilated meteorological fields in other format, such as NCEP/NCAR reanalysis (Kalnay et al., 1996). The optimal global analysis data are reduced or interpolated horizontally and verti- 
cally to adjust to the resolution of the GCM.

The FDDA system produces continuous meteorological fields that incorporate observed meteorological data. It enables simulating specific time periods, investigating the interannual variability, and providing chemical retrieval and forecasts for experimental field campaigns.

\subsection{Advection}

The advective transport for trace species in the model is performed using a semi-Lagrangian advection scheme (Staniforth and Côté, 1991). The semi -Lagrangian advection scheme permits the use of much larger time steps than the Eulerian advection scheme, without sacrificing the numerical stability and accuracy. The semi-Lagrangian scheme is three -dimensional, i.e., it first searches for the upstream point with both horizontal and vertical wind, then derives the mixing ratio with three-dimensional interpolation. The interpolation scheme first calculates the third-order interpolated value, then corrects the overshoot or undershoot advective flux with first-order interpolation for mass conservation and non-negative treatment.

\subsection{Eddy Diffusion}

Vertical eddy diffusion is an essential process for determining the distributions of trace constituents emitted from the ground surface. The eddy diffusive transport produced by the turbulent mixing process is expressed as

$$
\left(\frac{\partial \mu_{i}}{\partial_{t}}\right)_{\text {diffusion }}=\frac{\partial}{\partial z}\left(K_{z} \frac{\partial \mu_{i}}{\partial z}\right)
$$

where $K_{z}$ is the vertical eddy diffusion coefficient. The $K_{z}$ for the trace gases and aerosols is taken from that for water vapor in the GCM, which is calculated with the level 2 turbulence closure scheme by Mellor and Yamada (1974). The eddy diffusion equation (3) is solved by the tridiagonal algebraic systems, simultaneously with gravitational settling, dry depositions, and emission fluxes.

\subsection{Gravitational Settling and Dry Deposition}

Aerosol particles undergo gravitational settling relative to the air motion and are assumed to fall with the terminal velocity $V_{s} . V_{s}$ is calculated assuming that the particles are spherical and is expressed as

$$
V_{s}=2 C_{c}\left(\rho_{p}-\rho_{a}\right) g r_{p}^{2} /(9 \mu)
$$

where $\rho_{a}$ is the air density, $\rho_{p}$ and $r_{p}$ are the density and radius of the particle, $g$ is the gravitational acceleration, and $\mu$ is the viscosity of the air. $C_{c}$ is the Cunningham slip-flow correction and is expres- sed as,

$$
C_{c}=1+\mathrm{K}_{\mathrm{n}}\left[A+B \exp \left(-C / \mathrm{K}_{\mathrm{n}}\right)\right]
$$

where $K_{n}$ is the Knudsen number for air, and the coefficients $A, B$ and $C$ are set to $1.257,0.4$, and 1 . 1 , respectively.

At the ground surface, aerosol particles and some gases are removed by dry deposition processes. Dry deposition is calculated by the resis-tance analog model, which treats deposition velocities as the inverse of the sum of resistances (Seinfeld and Pandis, 1997). Dry deposition velocities for aerosol particles and for gases are expressed as

$$
\nu_{d}=\frac{1}{r_{a}+r_{b}+r_{a} r_{b} V_{s}}+V_{s}
$$

and

$$
\nu_{d}=\frac{1}{r_{a}+r_{b}+r_{c}}
$$

respectively. In equations (6) and (7), $r_{a}$ is the aerodynamic resistance, $r_{b}$ is the quasi-laminar resistance, and $r_{c}$ is the canopy resistance.

Aerodynamic resistance $r_{a}$ at reference height $z_{r}$ is

$$
r_{a}=\kappa u_{*} / \int_{z 0}^{z r} \phi_{h} \frac{d z}{z}
$$

where $\kappa$ is the von Kámán's constant, $u_{*}$ is the friction velocity, $z_{0}$ is the surface roughness length, and $\phi_{h}$ is the dimensionless potential temperature gradient. The reference height $z_{r}$ is set to $10 \mathrm{~m}$ for convenience. The integration of $\phi_{h}$ is calculated as a function of Monin-Obukhov length $L$,

$$
\int_{z 0}^{z r} \phi_{h} \frac{d z}{z}= \begin{cases}\operatorname{Pr}_{t} \ln \left(z_{r} / z_{0}\right)+\beta_{h}\left(\eta-\eta_{0}\right) \eta>0 \text { stable } \\ \operatorname{Pr}_{t}\left[\ln \frac{\sqrt{1-\gamma_{h} \eta}-1}{\sqrt{1-\gamma_{h} \eta}+1}-\ln \frac{\sqrt{1-\gamma_{h} \eta_{0}}-1}{\sqrt{1-\gamma_{h} \eta_{0}}+1}\right] \eta<0 \text { unstable(9) } \\ \operatorname{Pr}_{t} \ln \left(z_{r} / z_{0}\right) \quad \eta=0 \text { neutral }\end{cases}
$$

where $\eta=z / L, \eta_{0}=z_{0} / L$. The constants $\beta_{h}, \gamma_{h}$, and the turbulent Prandtl number $\operatorname{Pr}_{t}$, are $\beta_{h}=7.8, \gamma_{h}=$ 11.6, and $\operatorname{Pr}_{t}=0.95$ for $\kappa=0.4$ (Jacobson, 1999). The calculation of $r_{a}$ requires both $u_{*}$ and $L$. The $u_{*}$ over the land and $L$ are calculated within the CTM because the MJ98 GCM calculates $u_{*}$ over the ocean only. The non-iterative parameterization method developed by Louis (1979) is used to determine $u_{*}$ and $L$. The method first calculates the bulk Richardson number $\mathrm{Ri}_{b}$,

$$
\mathrm{Ri}_{b}=\frac{\mathrm{g}\left(\bar{\theta}_{\nu}\left(z_{r}\right)-\bar{\theta}_{\nu}\left(z_{0}\right)\right)\left(z_{r}-z_{0}\right)}{\bar{\theta}_{\nu}\left(z_{0}\right)\left|V_{h}\left(z_{r}\right)\right|^{2}}
$$

where $\bar{\theta}_{\nu}$ is the mean virtual potential temperature, and $V_{h}\left(z_{r}\right)$ is the horizontal wind speed at the reference height $z_{r}$. The friction velocity $u_{*}$ is then calculated as

$$
u_{*} \simeq \frac{\kappa\left|V_{h}\left(z_{r}\right)\right|}{\ln \left(z_{r} / z_{0}\right)} \sqrt{G_{m}}
$$


where

$G_{m}= \begin{cases}1-\frac{9.4 \mathrm{Ri}_{b}}{1+70 \kappa^{2} \sqrt{\left[\left|\mathrm{Ri}_{b}\right| z_{r} / z_{0}\right] / 1 n^{2}\left(z_{r} / z_{0}\right)}} & \mathrm{Ri}_{b} \leq 0 \\ \frac{1}{\left(1+4.7 \mathrm{Ri}_{b}\right)^{2}} & \mathrm{Ri}_{b}>0\end{cases}$

The Monin-Obukhov length $L$ is determined by

$$
L=\frac{u_{*}^{3} \bar{\theta}_{\nu}}{\kappa g H}
$$

where $\mathrm{H}$ is the sensitive heat flux.

The quasi-laminar resistances $r_{b}$ for aerosol particles and gases are given by

$$
r_{b}=\frac{1}{u_{*}\left(\mathrm{~S}_{\mathrm{c}}^{2 / 3}+10^{-3 / \mathrm{st}}\right)}
$$

and

$$
r_{b}=\frac{5 \mathrm{~S}_{\mathrm{c}}^{2 / 3}}{u_{*}}
$$

where Sc is the Schmidt number and St is the Stokes number (Seinfeld and Pandis, 1997).

The canopy resistance $r_{c}$ is based on the work of Wesely (1989) for $\mathrm{SO}_{2}$. For other water soluble gases, the $r_{c}$ of $\mathrm{SO}_{2}$ is applied to other water soluble gases (DMSO and $\mathrm{DMSO}_{2}$ ). We are aware of the fact that this approach is preliminary and this parameterization will be refined in the future model development.

\subsection{Cloud-related Processes}

Clouds interact with the trace species in several ways and are very important in determining the chemical compositions and lifetimes of the trace species. Parameterizations must be introduced since the cloud-related processes are very localized and cannot be resolved by the global model. The processes described in this section are wet deposition and convective transport. Aqueousphase reactions for sulfur chemistry are described in section 3 .

Wet deposition is distinguished between in -cloud and below-cloud scavenging and is also categorized by cloud type (convective or large -scale) and specie type (aerosol or gases; accommodation with water droplets). For in-cloud scavenging by large-scale precipitation, we used the parameterization developed by Giorgi and Chameides (1986). The loss rate $\lambda\left(\mathrm{s}^{-1}\right)$ due to in-cloud scavenging is expressed by

$$
\lambda=\frac{F\left(1-\exp \left(\beta T_{c}\right)\right)}{\Delta t}
$$

where $F$ is the fraction of the cloud in which the precipitation occurs, $T_{c}$ is the duration of the precipitation within the model time step, and $\beta$ is the frequency of conversion from cloud water to rain water. The parameters $F$ and $\beta$ are calculated from the rainwater formation rate and cloud amount generated by the model.
For water-soluble gases such as $\mathrm{SO}_{2}$, wet scavenging is simultaneously calculated with aqueousphase chemistry. The fraction of a water -soluble gas that is in the liquid water is assumed to follow Henry's law of equilibrium, which is temperature and $\mathrm{pH}$ dependent. The rate of wet deposition is calculated by the ratio of the new rainwater formation rate and the total water in the grid box (cloud water plus rainwater formation). For temperatures below $-20^{\circ} \mathrm{C}$, it is assumed that all the cloud droplets are frozen and the precipitation is snow, so that the wet scavenging of water-soluble gases is ignored, whereas aerosol particles are assumed to be scavenged by either rain or snow.

Evaporation of rainwater is considered in calculating the wet deposition rate. When evaporation occurs, a fraction of the trace elements is released back to the air. The fraction of the released trace elements is assumed to be proportional to the amount of evaporated rainwater.

The importance of transport in convective clouds of chemical species in the atmosphere has been emphasized by both observational (Ikegami et al., 1994) and model studies (Gidel, 1983 ; Chatfield and Crutzen, 1984 ; Costen et al., 1988 ; Allen et al., 1996). It has been pointed out that the convective transport parameterization is a major source of uncertainty in chemical transport models (Mahowald et al., 1995 ; Brasseur et al., 1999). It has also been pointed out that the soluble species are scavenged efficiently within the moist convective cloud updraft (Balkanski et al., 1993; Cohan et al., 1999).

The convective transport is calculated with mass flux (updraft and downdraft caused by the moist convection) by the Arakawa-Schubert moist convection scheme (Arakawa and Schubert, 1974) in the model. The algorithm first calculates the mixing ratio inside the convective updraft by solving the mass conservation equations for mass flux and the mixing ratios of chemical tracers, which are illustrated in Fig. 2 as follows:

$$
\frac{\partial M_{u}}{\partial z}=E-D
$$

and

$$
\frac{\partial\left(M_{u} \mu_{u}\right)}{\partial z}=E \mu_{e}-D \mu_{u}
$$

where $M, E$ and $D$ are convective mass flux, turbulent entrainment and detrainment, respectively. The subscripts " $u$ " and " $e$ " represent variables in the convective updraft and the environment. The entrainment is parameterized as

$$
E=\varepsilon M_{u},
$$

where $\varepsilon$ is the entrainment rate. The tendency of the 


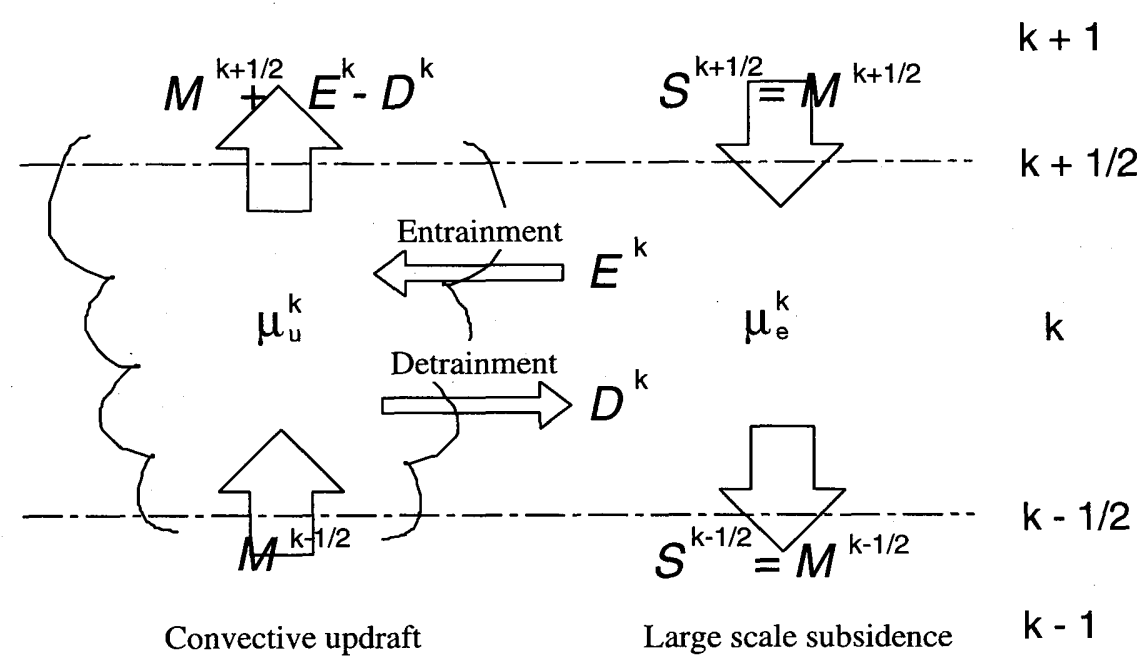

Figure 2. Schematic of algorithm for convective transport of trace species.

mixing ratio due to convective transport is then given as

$$
\left(\frac{\partial \mu}{\partial t}\right)_{\text {convection }}=\frac{1}{\rho} \frac{\partial}{\partial z}\left(M_{u} \mu_{u}-M_{u} \mu_{e}\right)
$$

where $\rho$ is the atmospheric density.

The equations (17) to (20) are integrated with shorter time steps than the advective transport in order to evaluate rapid convective motions and to obtain a more accurate solution. In practice, the time step for the convective transport is currently set to about 5 minutes.

\section{Aerosols Components Included in MASINGAR 3.1 General}

MASINGAR includes four major tropospheric aerosol species and their precursors; sulfur compounds, carbonaceous aerosols (black carbon+ organic carbon), sea-salt, and mineral dust. The annual mean emissions for sulfur compounds, carbonaceous, dust, and sea-salt aerosols are shown in Fig. 3. In addition to the aerosols, radon 222 and lead 210 are included to evaluate the transport and deposition process of the model. The chemical reaction equations are solved with the backward Euler method.

The properties of the aerosol species are summarized in Table 2. Note that the particle radius in Table 2 is the dry radius; hygroscopic aerosols change their sizes with water uptake from ambient moisture. The hygroscopic growth is parameterized with relative humidity according to Chin et al. (2002) and shown in Table 3.

The following subsections describe the chemistry and emissions of each aerosol species.

\subsection{Sulfur compounds}

The sulfur chemistry model treats. eight major sulfur compounds, sulfur dioxide $\left(\mathrm{SO}_{2}\right)$, sulfate $\left(\mathrm{SO}_{4}^{2-}\right)$, dimethyl sulfide (DMS), hydrogen sulfide $\left(\mathrm{H}_{2}\right.$ $\mathrm{S})$, carbon disulfide $\left(\mathrm{CS}_{2}\right)$, methane sulfonic acid (MSA), dimethyl sulfoxide (DMSO), and dimethyl sulfone $\left(\mathrm{DMSO}_{2}\right)$, and includes seven gasphase reactions and two aqueous - phase reactions. The gas -phase chemical reaction rates included in the model are summarized in Table 4. Most of the reaction rates are taken from DeMore et al. (1997) and Atkinson et al. (1992). The aqueous-phase reaction rates, aqueous-phase equilibrium constants, and Henry's law constants are taken from Seinfeld and Pandis (1997), and listed in Tables 5 and 6. Calculations of the reactions require the global distributions of oxidants $\mathrm{OH}, \mathrm{NO}_{3}, \mathrm{H}_{2} \mathrm{O}_{2}$, and $\mathrm{O}_{3}$, which are provided by Spivakovsky et al. (2000) as three-dimensional monthly averaged distributions. The monthly averaged concentrations are linearly interpolated in time for each time step. Concentrations of $\mathrm{OH}, \mathrm{NO}_{3}$ and $\mathrm{O}_{3}$ are assumed to be unaffected by the sulfur chemistry, while $\mathrm{H}_{2} \mathrm{O}_{2}$ is consumed by the aqueous-phase reactions with $\mathrm{S}$ (IV) and assumed to recover with a relaxation time of 12 hours. A diurnal variation of $\mathrm{OH}$ concentration is imposed by scaling the prescribed $\mathrm{OH}$ fields to the cosine of the solar zenith angle.

The model includes the emissions of $\mathrm{SO}_{2}, \mathrm{SO}_{4}^{2-}$ and $\mathrm{CS}_{2}$ from anthropogenic industrial activities and biomass burning; DMS and $\mathrm{CS}_{2}$ from the ocean; DMS and $\mathrm{H}_{2} \mathrm{~S}$ from terrestrial vegetation and soil ; and $\mathrm{SO}_{2}, \mathrm{SO}_{4}^{2-}$ and $\mathrm{H}_{2} \mathrm{~S}$ from continuous volcanic activities. Industrial sulfur emission is taken from the global $\mathrm{SO}_{x}\left(\mathrm{SO}_{2}+\mathrm{SO}_{4}^{2-}\right)$ inventory of 


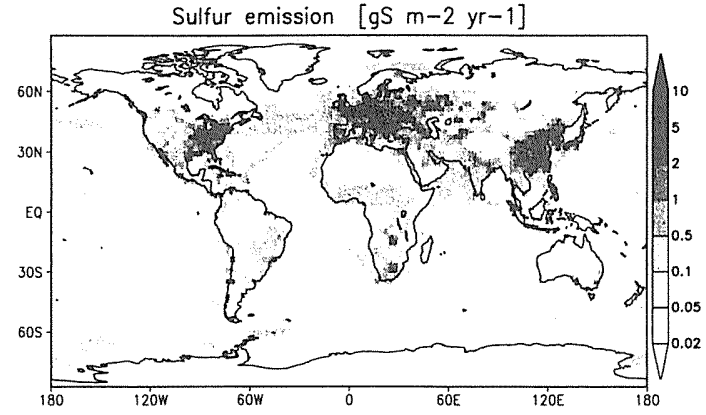

(a). Sulfur compounds

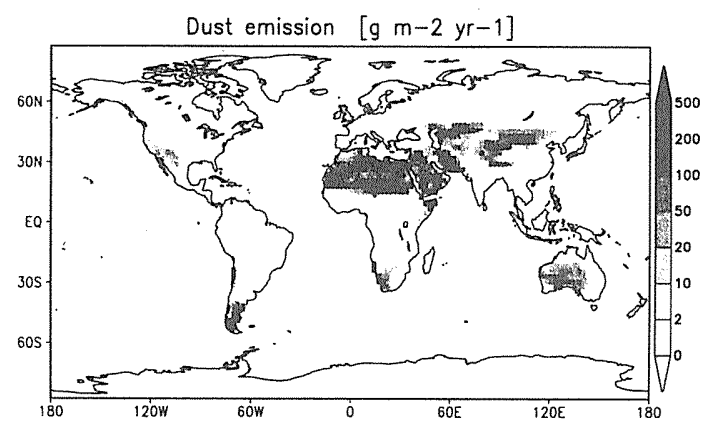

(c). Mineral dust

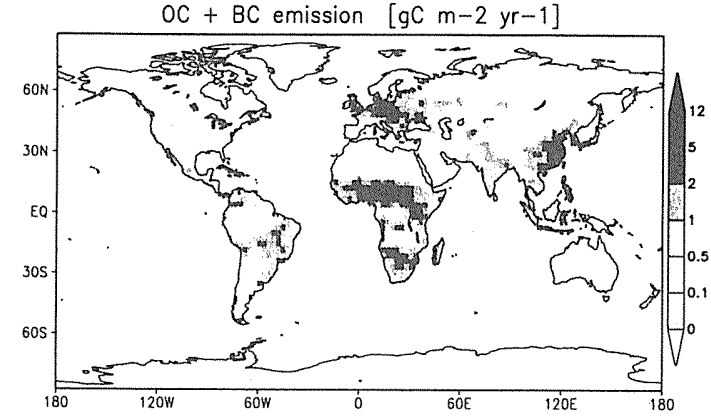

(b). Carbonaceous

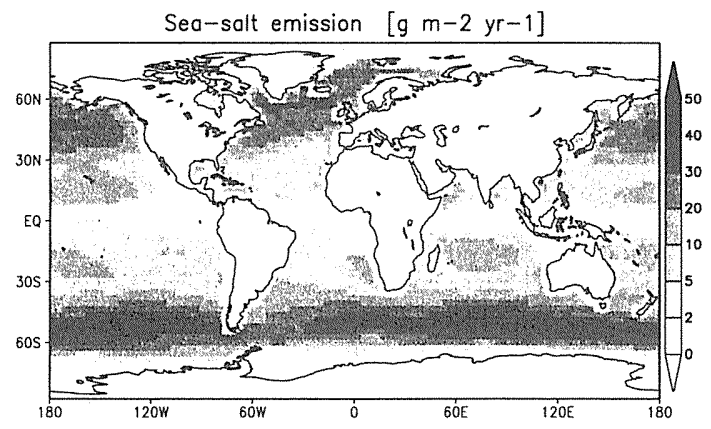

(d). Sea-salt

Figure 3. Annual mean emission rates at $\mathrm{T} 42$ resolution for (a) total sulfur compounds $\left(\mathrm{SO}_{2}+\right.$ $\left.\mathrm{SO}_{4}^{2-}+\mathrm{DMS}+\mathrm{H}_{2} \mathrm{~S}+\mathrm{CS}_{2}: \mathrm{gS} \mathrm{m} \mathrm{m}^{-2} \mathrm{~s}^{-1}\right),(\mathrm{b}) \mathrm{BC}+\mathrm{OC}\left(\mathrm{gC} \mathrm{m}^{-2} \mathrm{~s}^{-1}\right)$, (c)mineral dust $\left(\mathrm{g} \mathrm{m}^{-2}\right.$ $\left.\mathrm{s}^{-1}\right)$, and $(\mathrm{d})$ sea-salt $\left(\mathrm{g} \mathrm{m}^{-2} \mathrm{~s}^{-1}\right)$.

Table 2. Particle properties of the aerosol species in the model. For mineral dust and sea -salt, values in the parentheses are the volume mean radii.

\begin{tabular}{lcc}
\hline Type & Density & $r_{\text {dry }}$ \\
\hline Sulfate & 1.769 & 0.15 \\
OC & 1.5 & 0.18 \\
BC & 1.25 & 0.18 \\
Mineral dust & 2.5 & $0.100-0.158(0.136)$ \\
& 2.5 & $0.158-0.251(0.215)$ \\
& 2.5 & $0.251-0.398(0.340)$ \\
& 2.5 & $0.398-0.631(0.540)$ \\
& 2.5 & $0.631-1.000(0.855)$ \\
& 2.65 & $1.000-1.585(1.355)$ \\
& 2.65 & $1.585-2.512(2.148)$ \\
& 2.65 & $2.512-3.981(3.405)$ \\
Sea-salt & 2.65 & $3.981-6.310(5.396)$ \\
& 2.65 & $6.310-10.00(8.553)$ \\
& 2.25 & $0.100-0.158(0.136)$ \\
& 2.25 & $0.158-0.251(0.215)$ \\
& 2.25 & $0.251-0.398(0.340)$ \\
& 2.25 & $0.398-0.631(0.540)$ \\
& 2.25 & $0.631-1.000(0.855)$ \\
& 2.25 & $1.000-1.585(1.355)$ \\
& 2.25 & $1.585-2.512(2.148)$ \\
& 2.25 & $2.512-3.981(3.405)$ \\
& 2.25 & $3.981-6.310(5.396)$ \\
& 2.25 & $6.310-10.00(8.553)$ \\
\hline
\end{tabular}

Table 3. Hygroscopic growth factors as a function of relative humidity (Chin et al., 2002)

\begin{tabular}{lccccccc}
\hline RH (\%) & 0 & 50 & 70 & 80 & 90 & 95 & 99 \\
\hline Sulfate & 1 & 1.4 & 1.5 & 1.6 & 1.8 & 1.9 & 2.2 \\
OC & 1 & 1.2 & 1.4 & 1.5 & 1.6 & 1.8 & 2.2 \\
BC & 1 & 1.0 & 1.0 & 1.2 & 1.4 & 1.5 & 1.9 \\
Sea-Salt & 1 & 1.6 & 1.8 & 2.0 & 2.4 & 2.9 & 4.8 \\
\hline
\end{tabular}

the Emission Database for Global Atmospheric Research (EDGAR) (Olivier and Berdowski, 2001; Olivier et al., 2001), which is given for the representative years of 1990 and 1995. The global total $\mathrm{SO}_{x}$

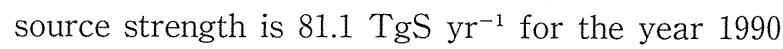

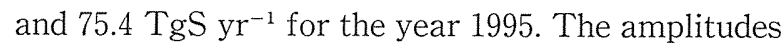
of seasonal variations and emission heights are taken from the Global Emission Inventory activity (GEIA) version 1B (Benkovitz et al., 1996; Voldner et al., 1996), which has four seasonal data and two vertical levels (below and above $100 \mathrm{~m}$ altitude). The inventory is converted to the model's horizontal grid, and interpolated in time with the cubic polynomial. A small fraction of anthropogenic $\mathrm{SO}_{2}$ is oxidized in the combustion chambers and emitted directly as sulfate, generally in the range of 1 to $5 \%$. 
Table 4. Reaction rates for gaseous reactions

\begin{tabular}{lll}
\hline \multicolumn{1}{c}{ Reactions } & \multicolumn{1}{c}{ Rate coefficients $\left(\mathrm{cm}^{-3} \mathrm{molec}^{-1} \mathrm{~s}^{-1}\right)$} & Reference \\
\hline $\mathrm{DMS}+\mathrm{OH} \longrightarrow \mathrm{SO}_{2}+\cdots$ & $9.6 \times 10^{-12} \exp (-234 / T)$ & $\mathrm{A}$ \\
$\mathrm{DMS}+\mathrm{OH} \longrightarrow 0.5 \mathrm{MSA}+0.5 \mathrm{DMSO}^{2} \cdots$ & $\frac{1.7 \times 10^{-42} \exp (7810 / T)\left[\mathrm{O}_{2}\right]}{1+5.5 \times 10^{-31} \exp (7460 / T)\left[\mathrm{O}_{2}\right]}$ & $\mathrm{A}, \mathrm{K}$ \\
$\mathrm{DMS}+\mathrm{NO}_{3} \longrightarrow \mathrm{CH}_{2} \mathrm{SCH}_{3}+\mathrm{HNO}_{3}$ & $1.9 \times 10^{-13} \exp (500 / T)$ & $\mathrm{D}$ \\
$\mathrm{DMSO}+\mathrm{OH} \longrightarrow 0.7 \mathrm{SO}_{2}+0.3 \mathrm{DMSO}_{2}$ & $5.8 \times 10^{-11}$ & $\mathrm{Y}$ \\
$\mathrm{H}_{2} \mathrm{~S}+\mathrm{OH} \longrightarrow \mathrm{SO}_{2}+\cdots$ & $6.0 \times 10^{-12} \exp (-75 / T)$ & $\mathrm{D}$ \\
$\mathrm{CS}_{2}+\mathrm{OH} \longrightarrow \mathrm{SO}_{2}+\mathrm{OCS}+\cdots$ & $\frac{1.25 \times 10^{-16} \exp (4550 / T)}{T+1.81 \times 10^{-3} \exp (3400 / T)}$ & $\mathrm{H}$ \\
$\mathrm{SO}_{2}+\mathrm{OH}+\mathrm{M} \longrightarrow \mathrm{SO}_{4}^{2-}+\cdots$ & $\frac{k_{0}[\mathrm{M}]}{1+k_{0}[\mathrm{M}] / k_{\infty}} \times 0.6^{\left.\left.1 /\left\{1+\left(\log _{10}\left(k_{0}\right] \mathrm{M}\right] / k_{\infty}\right)\right)^{2}\right\}}$ & $\mathrm{D}$ \\
& with $k_{0}=3.0 \times 10^{-31} \times(300 / T)^{3.3}$, & \\
& and $k_{\infty}=1.5 \times 10^{-12}$ & \\
\hline
\end{tabular}

[M]: air density (molecules $\mathrm{cm}^{-3}$ )

$\left[\mathrm{O}_{2}\right]$ : oxygen density (molecules $\mathrm{cm}^{-3}$ )

Sources: A: Atkinson et al. (1992), D: DeMore et al. (1997), H: Hynes et al. (1988), K: Koga (1993), Y: Yin et al. (1990)

Table 5. Henry's law constants and equilibrium constants used in the model

\begin{tabular}{lccc}
\hline Reactions & Coefficient & $K_{298}(\mathrm{M} \mathrm{atm}$ & $-\Delta H / R(K)$ \\
\hline $\mathrm{H}_{2} \mathrm{O}_{2}(\mathrm{~g}) \rightleftharpoons \mathrm{H}_{2} \mathrm{O}_{2}(\mathrm{aq})$ & $K_{\mathrm{H}_{2} \mathrm{O}_{2}}$ & $7.45 \times 10^{4}$ & 7301 \\
$\mathrm{O}_{3}(\mathrm{~g}) \rightleftharpoons \mathrm{O}_{3}(\mathrm{aq})$ & $K_{\mathrm{O}_{3}}$ & $1.13 \times 10^{-2}$ & 2537 \\
$\mathrm{SO}_{2}(\mathrm{~g})+\mathrm{H}_{2} \mathrm{O} \rightleftharpoons \mathrm{SO}_{2} \cdot \mathrm{H}_{2} \mathrm{O}$ & $K_{s H}$ & 1.23 & 3147 \\
$\mathrm{SO}_{2} \cdot \mathrm{H}_{2} \mathrm{O} \rightleftharpoons \mathrm{HSO}^{-}+\mathrm{H}^{+}$ & $K_{s 1}$ & $1.3 \times 10^{-2}$ & 1960 \\
$\mathrm{HSO}_{3}^{-} \rightleftharpoons \mathrm{SO}_{3}^{2-}+\mathrm{H}^{+}$ & $K_{s 2}$ & $6.6 \times 10^{-8}$ & 1500 \\
$\mathrm{HSO}_{4}^{-} \rightleftharpoons \mathrm{H}^{+}+\mathrm{SO}_{4}^{2-}$ & $K_{\mathrm{SO}_{4}}$ & $1.02 \times 10^{-2}$ & 2720 \\
$\mathrm{CO}_{2}(\mathrm{~g})+\mathrm{H}_{2} \mathrm{O} \rightleftharpoons \mathrm{CO}_{2} \cdot \mathrm{H}_{2} \mathrm{O}$ & $K_{c H}$ & $3.4 \times 10^{-2}$ & 2242.3 \\
$\mathrm{CO}_{2} \cdot \mathrm{H}_{2} \mathrm{O} \rightleftharpoons \mathrm{HCO}^{-}+\mathrm{H}^{+}$ & $K_{c 1}$ & $4.3 \times 10^{-7}$ & -1000 \\
$\mathrm{HCO}_{3}^{-} \rightleftharpoons \mathrm{CO}_{3}^{2-}+\mathrm{H}^{+}$ & $K_{c 2}$ & $4.68 \times 10^{-11}$ & 1760 \\
$\mathrm{H}_{2} \mathrm{O} \rightleftharpoons \mathrm{H}^{+}+\mathrm{OH}^{-}$ & $K_{w}$ & $10^{-14}$ & 6710.0 \\
\hline
\end{tabular}

Source: Seinfeld and Pandis (1997)

Table 6. Reaction rate expressions for the oxidation of S(IV) in aqueous phase

\begin{tabular}{lc}
\hline Reactions & Rate coefficients \\
\hline $\mathrm{S}(\mathrm{IV})+\mathrm{O}_{3} \longrightarrow \mathrm{SO}_{4}^{2-}+\mathrm{O}_{2}$ & $\frac{k_{a}+k_{b} K_{s 1} /\left[\mathrm{H}^{+}\right]+k_{c} K_{s 1} K_{s 2} /\left[\mathrm{H}^{+}\right]^{2}}{1+\left(K_{s 1} /\left[\mathrm{H}^{+}\right]\right)\left(1+K_{s 2} /\left[\mathrm{H}^{+}\right]\right)}\left[\mathrm{O}_{3}\right]$ \\
& with $\begin{array}{c}k_{a}=2.4 \times 10^{4} \\
k_{b}=3.7 \times 10^{5} \exp (-5530 / T) \\
k_{c}=1.5 \times 10^{9} \exp (-5280 / T)\end{array}$ \\
$\mathrm{S}(\mathrm{IV})+\mathrm{H}_{2} \mathrm{O}_{2} \longrightarrow \mathrm{SO}_{4}^{2-}+\mathrm{H}_{2} \mathrm{O}$ & $\frac{k_{d}\left[\mathrm{H}^{+}\right]\left(1+K\left[\mathrm{H}^{+}\right]\right)^{-1}}{1+\left[\mathrm{H}^{+}\right] / K_{s 1}+K_{s 2} /\left[\mathrm{H}^{+}\right]}\left[\mathrm{H}_{2} \mathrm{O}_{2}\right]$ \\
& with $\begin{array}{l}k_{d}=7.5 \times 10^{7} \exp (-4430 / T) \\
K=13\end{array}$ \\
\hline
\end{tabular}

Source: Seinfeld and Pandis (1997)

$K_{s 1}$ and $K_{s 2}$ are listed in the Table 5.
For simplicity, we assumed that $3 \%$ of the anthropogenic $\mathrm{SO}_{x}$ emission is emitted in the form of sulfate (Warneck, 1999). Following Pham et al. (1995), the distribution of the anthropogenic emission of $\mathrm{CS}_{2}$ is assumed to be proportional to the $\mathrm{SO}_{2}$ emission, and the global emission rate is set to 0.3 TgS $\mathrm{yr}^{-1}$ according to Khalil and Rasmussen (1984).

Sulfur emissions from biomass burning is primarily in the form of $\mathrm{SO}_{2}$. The biomass burning emission is taken from the monthly mean distribu- 
tion of Spiro et al. (1992). The global emission rate of biomass burning according to this inventory is 2 . $3 \mathrm{TgS}^{-1}$. Other sulfur compounds, possibly $\mathrm{CS}_{2}$, $\mathrm{H}_{2} \mathrm{~S}$ and sulfate, might be emitted from biomass burning, but these are not included in the model because of the lack of emission rate information.

The most abundant biogenic sulfur compound is DMS which is released from oceanic phytoplankton. Its annual global emission rate is estimated between

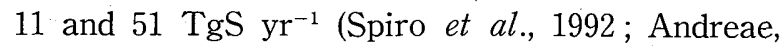
1990), making it the second largest sulfur emission following anthropogenic So $_{x}$ emission. The oceanic DMS emission flux is calculated as a function of surface seawater DMS concentration and the piston velocity. Climatological monthly averaged surface seawater DMS concentrations are adopted from Kettle et al. (1999). The piston velocity of DMS is calculated as a function of $10 \mathrm{~m}$ wind velocity and the Schmidt number of DMS at the sea-surface temperature. This model implementes two parameterizations of DMS piston velocity. First, the widely used empirical scheme of Liss and Merlivat (1986) is employed as the default scheme for DMS piston velocity.

$$
k_{\mathrm{DMS}}= \begin{cases}0.17 U_{10} & \text { for } U_{10} \leq 3.6 \\ 2.85 U_{10}-9.65 & \text { for } 3.6<U_{10} \leq 13 . \\ 5.9 U_{10}-49.3 & \text { for } U_{10}>13\end{cases}
$$

Second, the empirical scheme of Wanninkhof (1992) is implemented as an optional scheme.

$$
k_{\mathrm{DMS}}=0.31 u^{2}{ }_{10} \sqrt{660 / \mathrm{Sc}} .
$$

In either scheme, the Schmidt number of DMS is calculated by the formula from Saltzman et al. (1993)

$$
\mathrm{Sc}=2674.0-147.12 T+3.726 T^{2}-0.038 T^{3},
$$

where $T$ is the sea-surface temperature (in ${ }^{\circ} \mathrm{C}$ ). The oceanic DMS emission flux is suppressed when the sea surface is covered with ice, i.e., the DMS emission is proportional to (1-ocean ice coverage fraction). The DMS emission flux is a large source of uncertainty in the simulation, and we are planning a comparison study in the future. Oceanic emission of $\mathrm{CS}_{2}$ is assumed to be proportional to the emission of DMS, following Pham et al. (1995). The oceanic $\mathrm{CS}_{2}$

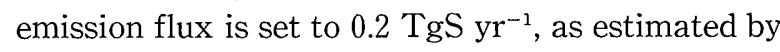
Andreae (1986).

Global emission distributions of terrestrial biogenic DMS, $\mathrm{H}_{2} \mathrm{~S}$, and $\mathrm{CS}_{2}$ are based on the inventories compiled by Spiro et al. (1992). The total emissions of DMS and $\mathrm{H}_{2} \mathrm{~S}$ from terrestrial vegeta-

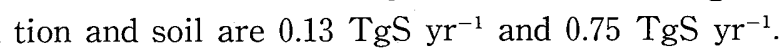
These are minor amounts relative to the oceanic
DMS emissions.

The global source distribution from volcanos is taken from the inventory of Global Emissions Inventory Activity (GEIA) (Andres and Kasgnoc, 1998). The current version of the model considers only emission flux from the non-eruptive volcanos. The total $\mathrm{SO}_{2}$ emission rate from the non-eruptive vol-

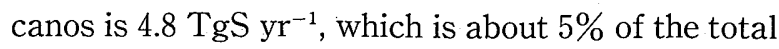
sulfur emissions. Sulfur emission fluxes from volcanos are primarily in the form of $\mathrm{SO}_{2}$, together with minor emissions of $\mathrm{H}_{2} \mathrm{~S}, \mathrm{CS}_{2}, \mathrm{OCS}$ and $\mathrm{SO}_{4}^{2-}$. For the emission flux of $\mathrm{H}_{2} \mathrm{~S}, \mathrm{CS}_{2}$, and $\mathrm{SO}_{4}^{2-}$, we adopted the following emission ratios derived by Andres and Kasgnoc (1998): $\mathrm{H}_{2} \mathrm{~S} / \mathrm{SO}_{2}=0.21, \mathrm{CS}_{2} /$ $\mathrm{SO}_{2}=0.022$, and $\mathrm{SO}_{4}^{2-} / \mathrm{SO}_{2}=0.034$. The total emission rates of $\mathrm{H}_{2} \mathrm{~S}, \mathrm{CS}_{2}$ and $\mathrm{SO}_{4}^{2-}$ from the non -eruptive volcanos are $1.0 \mathrm{TgS} \mathrm{yr}^{-1}, 0.10 \mathrm{TgS} \mathrm{yr}^{-1}$, and $0.16 \mathrm{TgS} \mathrm{yr}^{-1}$.

\subsection{Carbonaceous Aerosols}

Carbonaceous aerosols are classified into black carbon (BC) and organic carbon (OC). We assume that $80 \%$ of $\mathrm{BC}$ and $50 \%$ of $\mathrm{OC}$ are emitted as hydrophobic material, following Cooke et al. (1999). We also assume that the hydrophobic carbonaceous aerosols become hydrophilic with aging in an e -folding time of 1.2 days (Chin et al., 2002). Hydrophobic carbonaceous aerosols are scavenged by dry deposition only, whereas hydrophilic carbonaceous aerosols are scavenged by both dry and wet deposition. No chemical sinks for carbonaceous aerosols are assumed in this model. The particle densities of $\mathrm{OC}$ and $\mathrm{BC}$ are assumed to be 1.5 and $1.25 \mathrm{~g} \mathrm{~cm}^{-3}$ (Takemura et al., 2000).

Sources of carbonaceous aerosols are roughly divided into anthropogenic emissions, biomass burning, and volatile organic compound (VOC) gases. The annual mean anthropogenic black carbon emission, monthly mean biomass burning black carbon emission, and monthly mean terpene emission are adopted from the $1^{\circ} \times 1^{\circ}$ resolution maps of GEIA databases (Cooke and Wilson, 1996 ; Guenther et $a l ., 1995)$. Following Liousse et al. (1996), we assume a biomass burning $\mathrm{OC}$ : $\mathrm{BC}$ emission ratio of 8.28 for tropical forests, and 6.92 for others, represents a more incomplete burning condition over tropical forests. The forest types are specified according to the $1^{\circ} \times 1^{\circ}$ land use map derived from AVHRR data of DeFries and Townshend (1994). The OC: BC emission ratio for anthropogenic emission is assumed to be 3.33 (Liousse et al., 1996). Annual total direct emission of $\mathrm{BC}$ and $\mathrm{OC}$ are $18.6 \mathrm{TgC}$

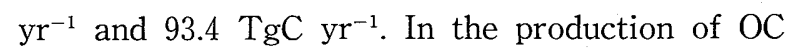
aerosol from a terrestrial emission of VOCs, we 
assume that terpene is converted to OC by gas-to -particle conversion. The emission inventory of Guenther et al. (1995) is used for the monthly mean terpene emission. We assume $10 \%$ of terpene emit ted is converted to OC aerosol (Chin et al., 2002). This secondary source of OC accounts for $11.8 \mathrm{TgC}$ $\mathrm{yr}^{-1}$.

\subsection{Mineral Dust}

Recent studies of mineral dust aerosol suggest that mineral dust has large climatic impacts (e.g., Tegen et al., 1996; Herman et al., 1997 ; Sokolik et $a l .$, 1998). In the model, mineral dust aerosol is logarithmically divided into 10 size divisions from 0 . 1 to $10 \mu \mathrm{m}$ in radius, which are treated independently. Following Tegen and Fung (1994), the particle density of dust aerosol is assumed to be $2.5 \mathrm{~g} \mathrm{~cm}^{-3}$ for clay particles $(r<1 \mu \mathrm{m})$, and $2.65 \mathrm{~g} \mathrm{~cm}^{-3}$ for particles larger than $1 \mu \mathrm{m}$.

The emission flux of mineral dust aerosol depends on meteorological, geographical and soil surface conditions, such as wind speed, atmospheric stability, land use, vegetation, soil moisture, and soil types. The current version of MASINGAR uses an emission flux scheme based on the schemes of Tegen and Fung (1994) and Takemura et al. (2000), which are further based on the empirical approach of Gillette (1978). The dust emission flux $F$ is expressed as a function of wind speed at $10 \mathrm{~m}\left(U_{10}\right)$ and the threshold wind velocity $U_{t}$;

$F=C M A \frac{W_{g t}-W_{g}}{W_{g t}}\left(U_{10}-U_{t}\right) U_{10}^{2}$ for $U_{10} \geq U_{t}(24)$

where $C$ is a dimensional factor (currently set to 0 . 7 , according to Tegen and Fung (1994)), $M$ is the ratio of mass of dust in the size bin to total mass, $A$ is the erodible fraction of the surface, $W_{g}$ is the soil moisture, and $W_{g t}$ is the threshold soil moisture (currently set to 0.3 ). The threshold wind velocity $U_{t}$ is set to $6.5 \mathrm{~m} \mathrm{~s}^{-1}$, following Tegen and Fung (1994) and Takemura et al. (2000). The relative mass ratio $M$ is calculated by the assumed simple size distribution described in Woodward (2001). The erodible fraction $A$ is determined from the land use, soil type, and vegetation fraction. In this model, the land use map of DeFries and Townshend (1994) is used to locate the arid and semi-arid regions. Emission locations are limited to the bare ground, shrubs/bare ground, and grassland. Currently, the vegetation fraction is taken from the land surface model of the MJ98 GCM (SiB).

\subsection{Sea-Salt}

Strong winds over the ocean surface produce sea-salt due to bursting of air bubbles during whitecap formation (indirect mechanism) and direct production by spume. We adopted an empirical parameterization of the production mechanisms developed by Gong et al. (1997) and Monahan et al. (1986). The density function $d F / d r$ (particles $\mathrm{m}^{-2} \mathrm{~s}$ ${ }^{-1} \mu \mathrm{m}^{-1}$ ) of the sea-salt production rate by indirect mechanisms is

$\frac{d F_{0}}{d r}=1.373 U_{10}^{3.41} r^{-3}\left(1+0.057 r^{1.05}\right) \times 10^{\left(1.19 \exp \left(-B^{2}\right)\right)}$

where $U_{10}$ is the wind speed at $10 \mathrm{~m}\left(\mathrm{~m} \mathrm{~s}^{-1}\right), r$ is the particle radius $(\mu \mathrm{m})$, and $B=(0.380-\log (r))=0.650$. The direct mechanism is neglected because of its large size range.

Sea-salt aerosol is logarithmically divided into 10 size bins ranging from 0.1 to $10 \mu \mathrm{m}$ in radius. The sea-salt emission flux of each size bin is calculated by integrating the equation (25) over the size range of each size bin.

\section{Results}

This section briefly discusses model results of the global distribution of aerosols. Table 7 summarizes the global budget of each aerosol type. The results presented from sections 4.1 to 4.4 are at a horizontal resolution of T42 with 30 vertical layers, and are not applied to the assimilation by the FDDA system. They should be considered as the results of the typical meteorological year, rather than of any specific year or a period. The capability of the FDDA system to simulate the meteorological fields of a specific period is illustrated in section 4.5 .

Table 7. Global budget of sources, sinks, atmospheric burden, and lifetimes of different types of aerosols

\begin{tabular}{crrrrc}
\hline $\begin{array}{c}\text { Aerosol } \\
\text { Type }\end{array}$ & $\begin{array}{r}\text { Source } \\
\left(\mathrm{Tg} \mathrm{yr}^{-1}\right)\end{array}$ & $\begin{array}{r}\text { Dry deposition } \\
\left(\mathrm{Tg} \mathrm{yr}^{-1}\right)\end{array}$ & $\begin{array}{r}\text { Wet deposition } \\
\left(\mathrm{Tg} \mathrm{yr}^{-1}\right)\end{array}$ & $\begin{array}{r}\text { Total burden } \\
(\mathrm{Tg})\end{array}$ & $\begin{array}{r}\text { Lifetime } \\
(\text { days })\end{array}$ \\
\hline Sulfate & 42.3 & 5.98 & 36.3 & 1.10 & 9.5 \\
OC & 94.7 & 13.23 & 81.5 & 1.81 & 7.0 \\
BC & 18.1 & 2.90 & 15.2 & 0.37 & 7.5 \\
Dust & 4499.0 & 2195.9 & 2300.5 & 59.9 & 4.9 \\
Sea salt & 6318.4 & 5132.2 & 1188.8 & 10.3 & 0.6 \\
\hline
\end{tabular}




\subsection{Sulfate Aerosol}

The annual mean surface concentration (in the lowest dynamic layer), column burden, and zonal mean latitude-height cross section of the sulfate aerosol are shown in Figure 4. The spatial patterns of the distributions are fairly similar to those simulated in previous studies (e.g., Langner and Rodhe, 1991; Pham et al., 1995; Feichiter et al., 1996 ; Roelofs et al., 1998; Koch et al., 1999; Lohmann et al., 1999 ; Barth et al., 2000 ; or Chin et al., 2000 ), with maxima over and around the industrialized areas, reflecting the predominant source of anthropogenic $\mathrm{SO}_{x}$ emission. Over the southern hemisphere, the influence of anthropogenic $\mathrm{SO}_{x}$ emission is relatively weak, and the sulfate concentration is mainly controlled by the biogenic emission of DMS.

The distribution of column-integrated sulfate (Fig. 4b) has a pattern similar to that of the surface distribution (Fig. 4a), reflecting that the sulfate aerosols are mainly concentrated in the lower troposphere. The zonal mean latitudeheight cross section of sulfate (Fig. 4c) exhibits a maximum at the middle latitude of the northern hemisphere because of the industrial activities. High con-centrations of sulfate aerosols are transported into the Arctic region, as reported by observations (e.g., Barrie and Barrie, 1990).

The annual total source strength of sulfate is $42.3 \mathrm{TgS} \mathrm{yr}^{-1}$, which is mostly from the oxidation of $\mathrm{SO}_{2}$. In this model, about half of the $\mathrm{SO}_{2}$ emitted from the ground is oxidized to sulfate. The lifetime of sulfate aerosol is 9.5 days, which exceeds that of other aerosol types because the sources of sulfate (gas-to-particle conversion) are at higher altitudes, and sulfate is in a small particle size region.

\subsection{Carbonaceous Aerosols}

Figure 5 illustrates the annual mean surface concentrations, column burdens, and zonal mean distributions of carbonaceous aerosols. The spatial patterns of the distributions are similar to those in the previous studies (Liousse et al., 1996 ; Penner et al., 1998; Takemura et al., 2000; Chin et al., 2002). As a result of biomass burning, the carbonaceous aerosols are mostly concentrated over the tropical regions, especially in the equatorial region of Africa, South America, and Indochina. In addition to the biomass burning regions, relatively large concentrations over Europe, North America and China are simulated due to the fossil fuel consumption in those regions.

The lifetime of organic carbon is calculated as 7.0 days, and that of balck carbon, 7.5 days (Table

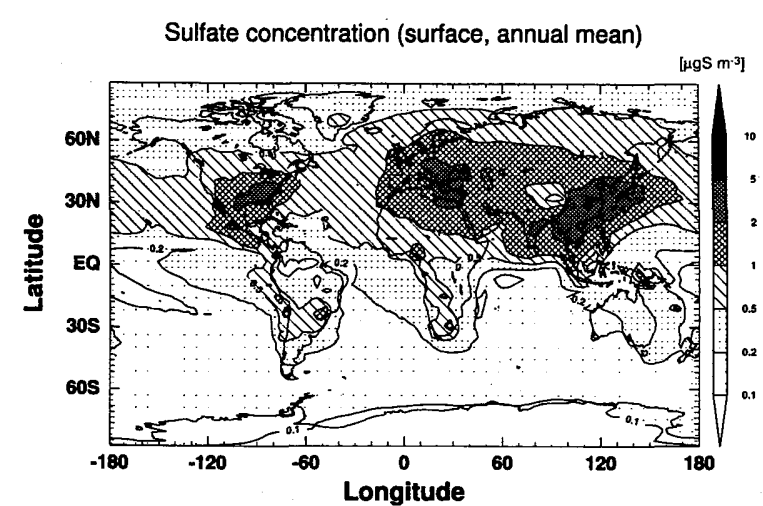

(a). Surface

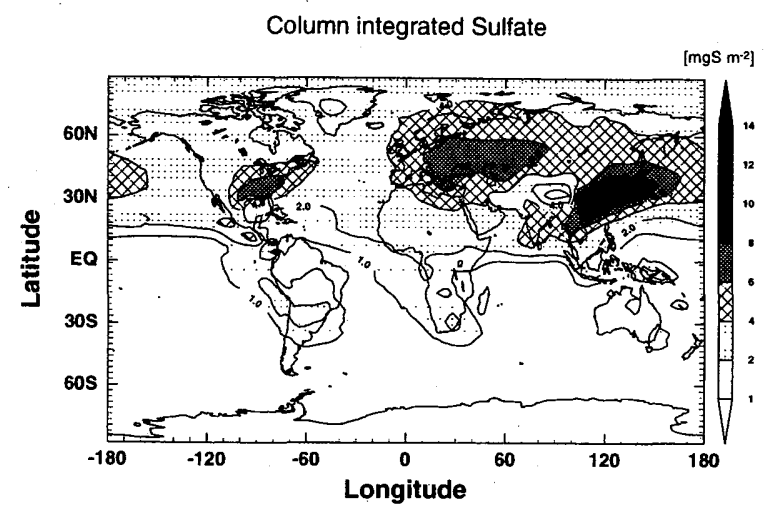

(b). Column burden

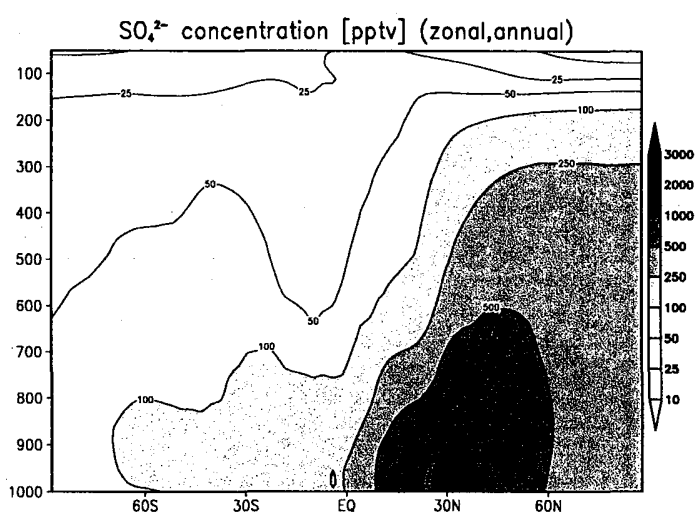

(c). Zonal mean

Figure 4. Annual mean distribution of sulfate aerosol. (a)Surface concentration ( $\mu \mathrm{gS} \mathrm{m}^{-3}$ ). (b)Column-integrated burden ( $\mathrm{mgS} \mathrm{m}^{-2}$ ). (c)Zonal mean latitude-height cross section $\left(\mu \mathrm{gS} \mathrm{m} \mathrm{m}^{-3}\right)$.

7). Wet deposition flux exceeds dry deposition flux for both $\mathrm{OC}$ and $\mathrm{BC}$ because the carbonaceous aerosols are assumed to be in the small size range. 


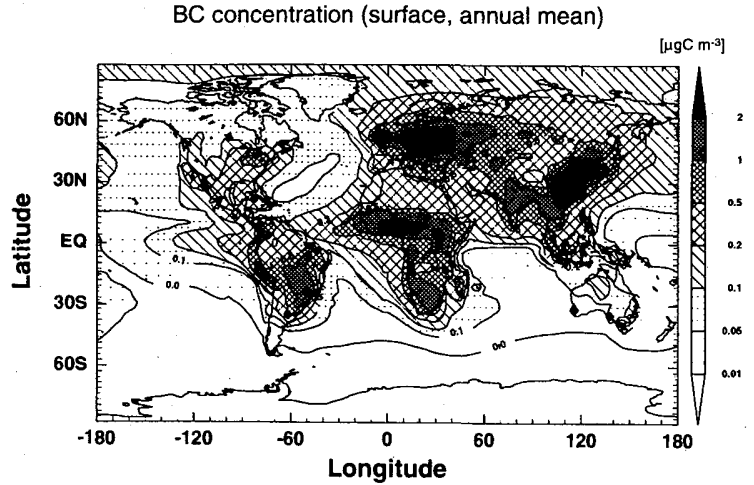

(a). Surface BC

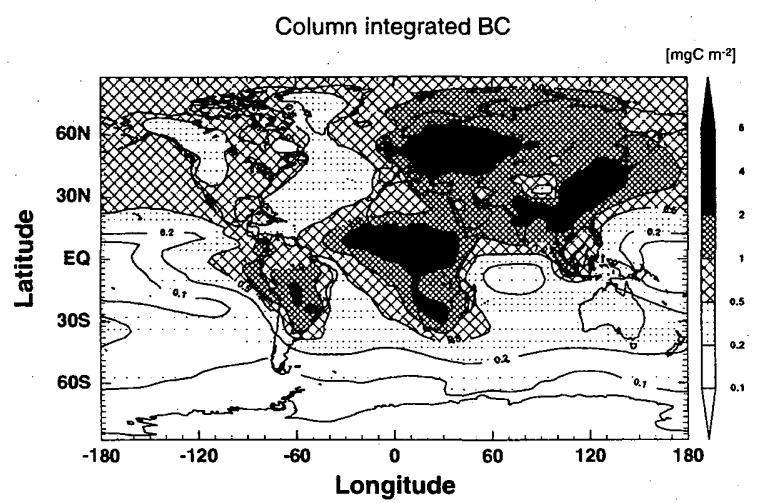

(c). BC Column burden

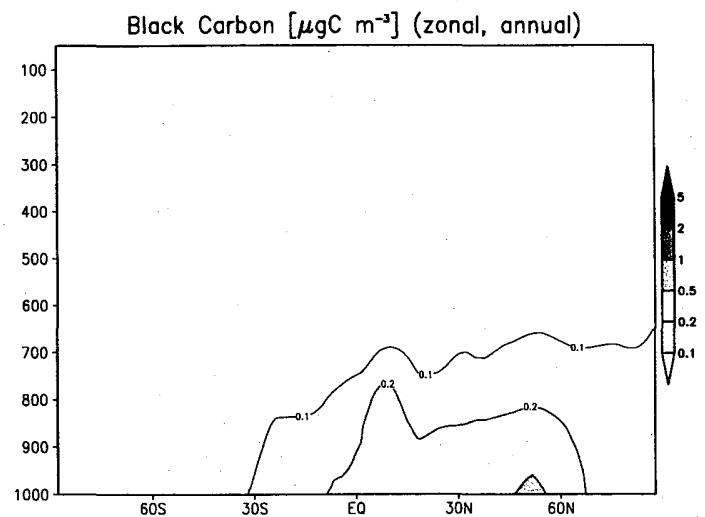

(e). BC zonal mean

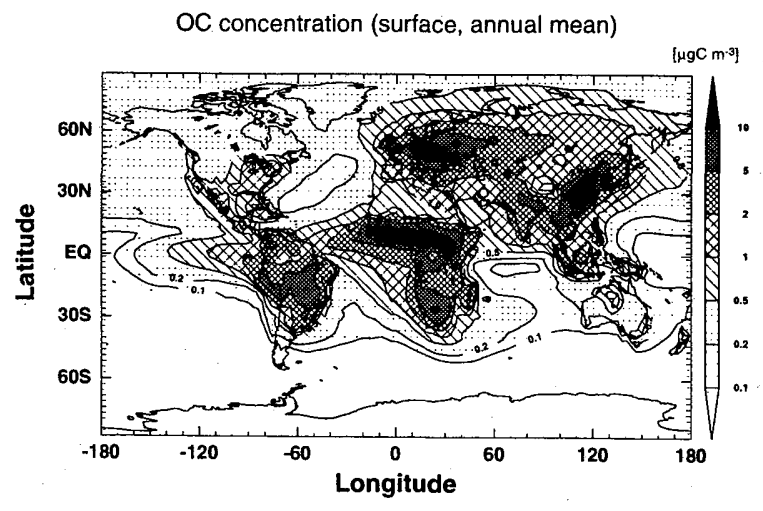

(b). Surface OC

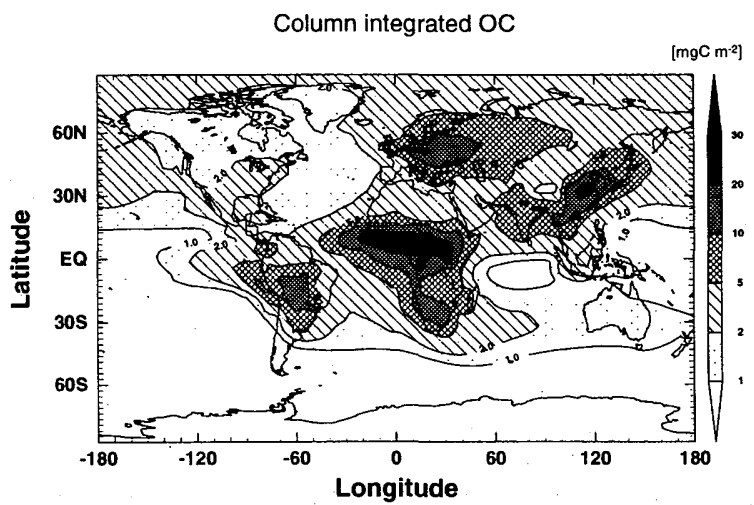

(d). OC Column burden

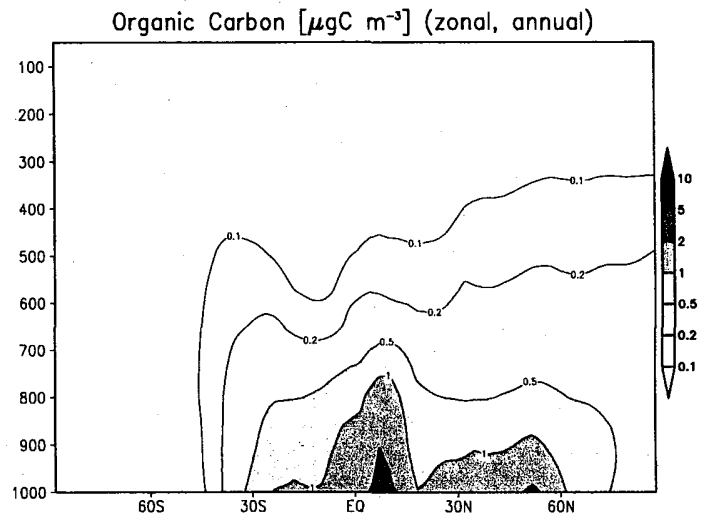

(f). OC zonal mean

Figure 5. Annual mean distributions of carbonaceous aerosols. (a)Surface concentration of BC $\left(\mu \mathrm{gC} \mathrm{m}{ }^{-3}\right)$. (b)Surface concentration of OC $\left(\mu \mathrm{gC} \mathrm{m}{ }^{-3}\right)$. (c)Column-integrated burden of $\mathrm{BC}\left(\mathrm{mgC} \mathrm{m}^{-2}\right)$. (d)Column-integrated burden of $\mathrm{OC}\left(\mathrm{mgC} \mathrm{m}^{-2}\right)$. (e)Zonal mean latitude-height cross section of $\mathrm{BC}\left(\mu \mathrm{gC} \mathrm{m} \mathrm{m}^{-3}\right)$. (f)Zonal mean latitude-height cross section of $\mathrm{OC}\left(\mu \mathrm{gC} \mathrm{m} \mathrm{m}^{-3}\right)$. 


\subsection{Mineral Dust}

Figure 6 presents the annual mean surface concentration, column burden, and zonal mean distribution of mineral dust aerosols. The simulated geographical distribution of mineral dust reflects the major source regions: North Africa (the Sahra desert), the Arabian Penisula, North China (Gobi and Takuramakan desert), and Australia. The model well reproduces the Saharan dust plume transported westward between $0^{\circ}$ and $30^{\circ} \mathrm{N}$ by the trade wind over the North Atlantic, where large values of the Aerosol Index are observed by satellites (Herman et al., 1997).

The zonal mean distribution (Fig. 6c) reaches a maximum at $10-20^{\circ} \mathrm{N}$, which corresponds to the dust from the Saharan and the Arabian sources. Over the mid latitude of the northern hemisphere, relatively

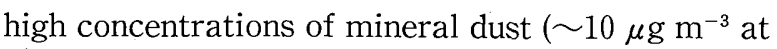
$500 \mathrm{hPa}$ ) are calculated. This is true because the deserts of the Asian continent (e.g., Takuramakan desert) are at a high altitude.

The global dust emission flux of particles with radii of 0.1 to $10 \mu \mathrm{m}$ is calculated as $4499 \mathrm{Tg} \mathrm{yr}^{-1}$, which is relatively high among those estimated by previously reported studies (between 200 and 3000 Tg $\mathrm{yr}^{-1}$ (Tegen and Fung, 1994)). In the model, the dust emission flux is very sensitive to the surface wind speed and the ground properties including land use, vegetation cover, snow cover, soil texture, and soil moisture. The quantitative evaluation of dust emission flux is still under development. We are planning to employ and evaluate more sophisticated emission models, such as emission scheme of Shao (2001). We also noticed that the dust emission amount depends on the model's grid resolution. If the grid resolution is changed, the dust emission flux will be affected due to the different surface wind speeds and ground properties. The dependence on the model resolution and the ground properties should be investigated in future studies. The lifetime of mineral dust aerosol is 4.9 days, which is relatively short due to the efficient dry deposition in the large size bins.

\subsection{Sea-Salt}

The annual mean surface concentration, column burden, and zonal mean distribution of sea-salt aerosols are shown in Fig. 7. The sea-salt aerosols are mostly concentrated over the ocean because the mass of sea-salt aerosol particles are mostly in the coarse size bins, and they are rapidly deposited by gravitational settling. The maximum concentration is found at middle latitudes, because of the strong surface winds over the ocean associated with the

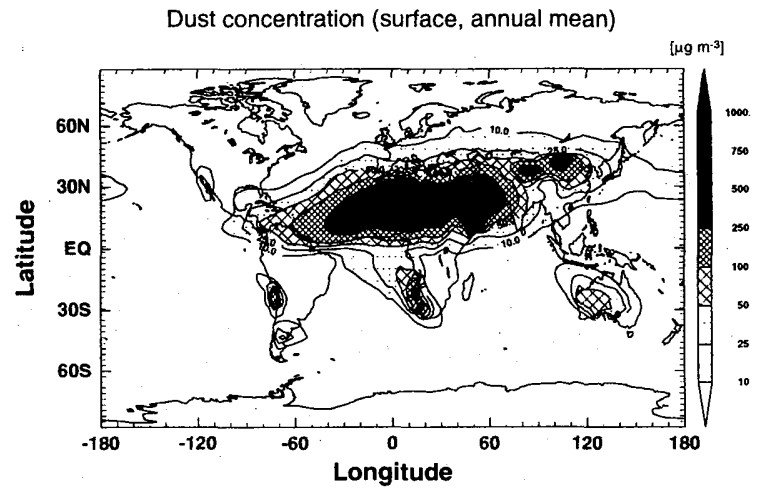

(a). Surface dust

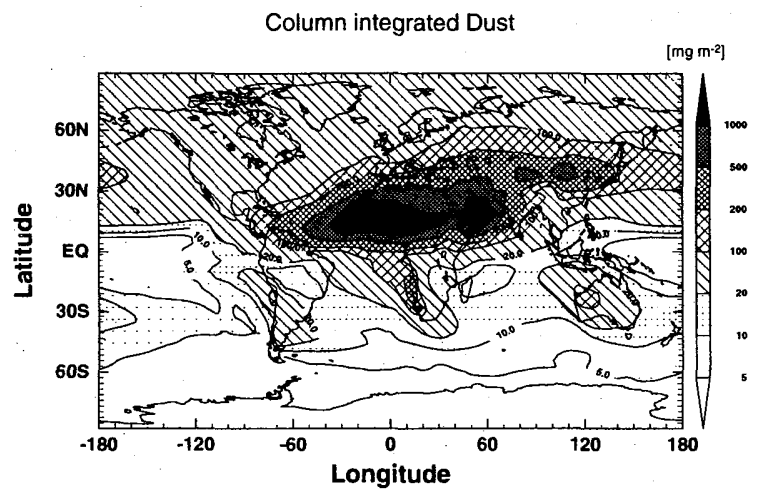

(b). Column burden

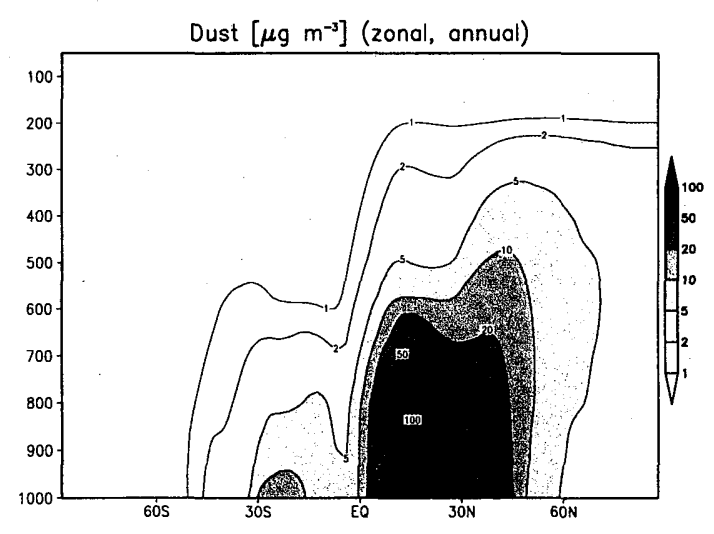

(c). Zonal mean

Figure 6. Annual mean distributions of mineral dust aerosol. (a)Surface concentration $\left(\mu \mathrm{g} \mathrm{m}^{-3}\right)$. (b)Column-integrated burden ( $\mathrm{mg} \mathrm{m}^{-2}$ ). (c)Zonal mean latitude-height cross section $\left(\mu \mathrm{g} \mathrm{m}^{-3}\right)$.

baroclinic disturbances. In contrast, concentrations are low over the tropical regions, due to the low surface wind speed.

The zonal mean distribution (Fig. 7c) indicates that the sea-salt aerosols are concentrated in the 


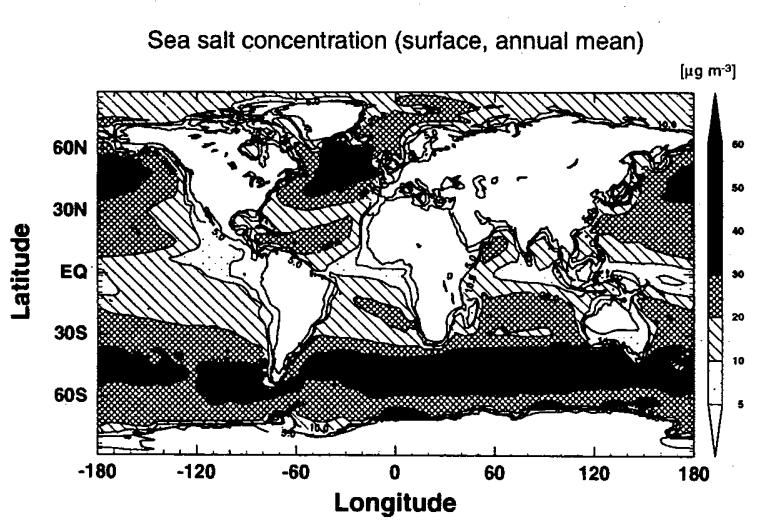

(a). Surface

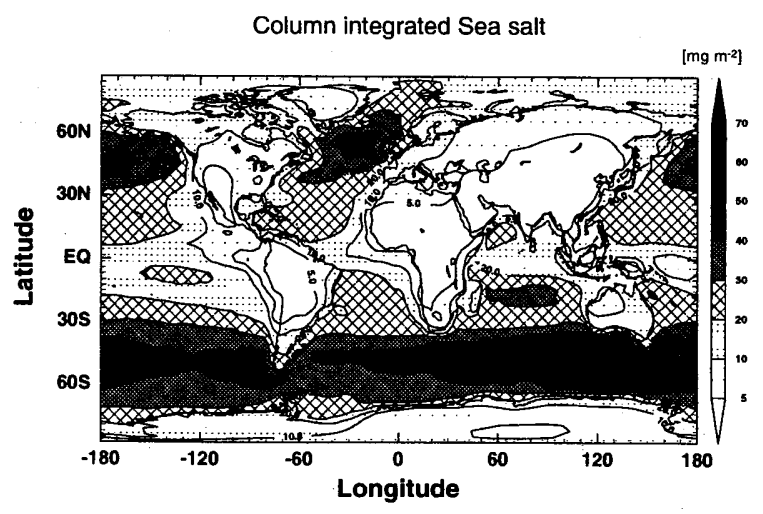

(b). Column burden

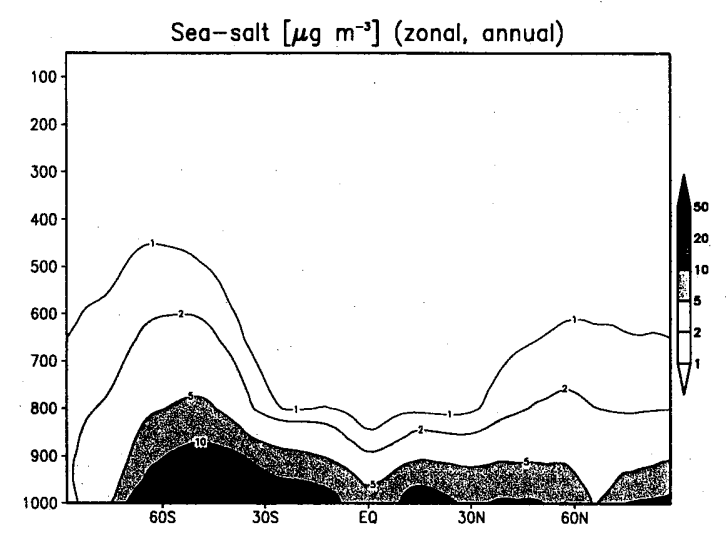

(c). Zonal mean

Figure 7. Annual mean distributions of sea-salt aerosol. (a)Surface concentration ( $\mu \mathrm{g}$ $\mathrm{m}^{-3}$ ). (b)Column-integrated burden ( $\mathrm{mg}$ $\mathrm{m}^{-2}$ ). (c)Zonal mean latitude-height cross section $\left(\mu \mathrm{g} \mathrm{m}^{-3}\right)$.

boundary layer. This is because most of the sea-salt aerosols are in the large size range, resulting in efficient dry deposition. Table 7 shows that the total dry deposition flux of sea-salt aerosol is four times larger than the total wet deposition flux.
The annual total global sea-salt emission flux of particles with radii of 0.1 to $10 \mu \mathrm{m}$ is calculated as $6318 \mathrm{Tg} \mathrm{yr}^{-1}$, which is the largest primary aerosol source. The lifetime of a sea-salt aerosol is 0.6 days, which is very short due to the efficient dry and wet deposition.

\subsection{Simulation with the Four-dimensional Data Assimilation}

In order to illustrate the capability of the model to simulate realistic meteorological fields with the FDDA system, we present and discuss a few specific "snapshots" of the calculated aerosol distributions in this section. From April 8 to 21, 2002, in situ sampling and lidar and skyradiometer network observation of mineral dust were conducted during the first intensive observational period (IOP-1) of the Aeolian Dust Experiment on the Climatic impact (ADEC) project (Mikami et al., 2002). During this period, MASINGAR was used to forecast the mineral dust aerosols, to support field measurements and to validate the model. A large dust storm event was observed in Beijing on April 6, and over $1000 \mu \mathrm{g} \mathrm{m}^{-3}$ of dust was reported in South Korea from April 8 to 9. On April 10, the "Kosa" phenomenon was reported throughout the mainland, Shiko$\mathrm{ku}$, and Kyushu of Japan. Figure 8 compares the simulated surface dust distribution and map of stations where the dust event was observed from April 8 to 10, 2002 over East Asia. The simulation is conducted with a horizontal resolution of $\mathrm{T} 42$ and 30 vertical layers. The maps of dust-observing stations are compiled from the SYNOP report World Meteorological Organization (1974), and described in Kurosaki and Mikami (2002). The distribution of observed points moves eastward from northern China on April 8 (Fig. 8a) to mainland Japan on April 10 (Fig. 8c). The simulated surface dust distribution corresponds well to the observed points. Although this method cannot quantitatively evaluate the model results, it suggests the simulated surface dust distribution reproduces the observed dust event reasonably well.

Figure 9 shows the simulated column-integrated dust amount and TOMS aerosol index (AI) (Herman et al., 1997) from April 8 to 10, 2002. Notice that the peak of the column-integrated dust is transported over the Japan Sea, where the center of a cyclone is located. Comparison with the TOMS AI shows relatively good correlation, although some differences can be observed. For example, dust over mainland Japan is not seen in TOMS AI, and the model does not have peaks over southern China. The inconsistencies may be caused by the sensitiv- 

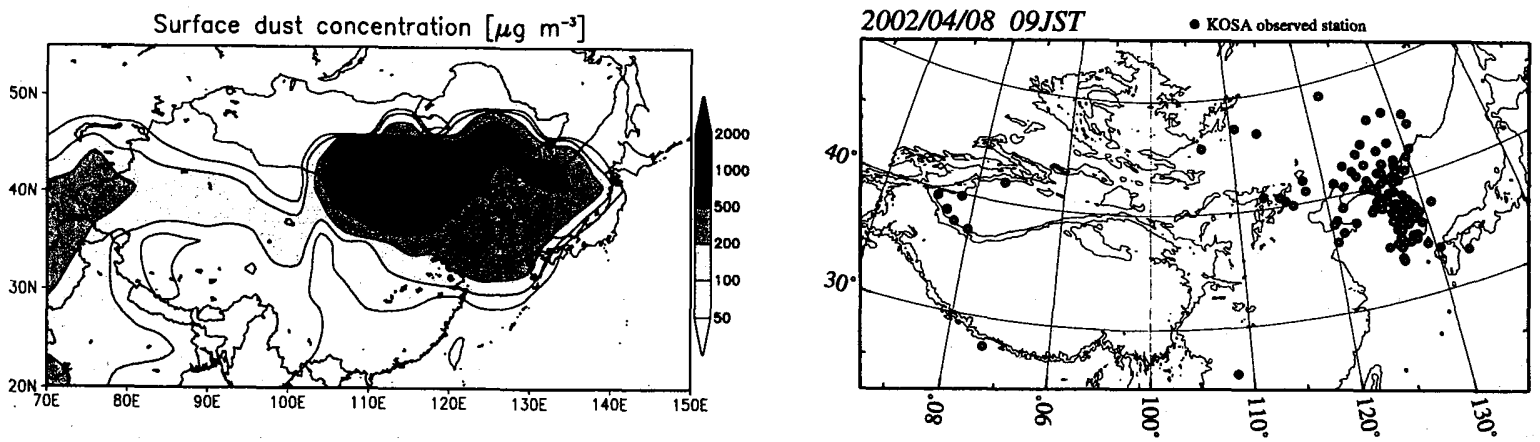

(a). 00Z April 8, 2002.
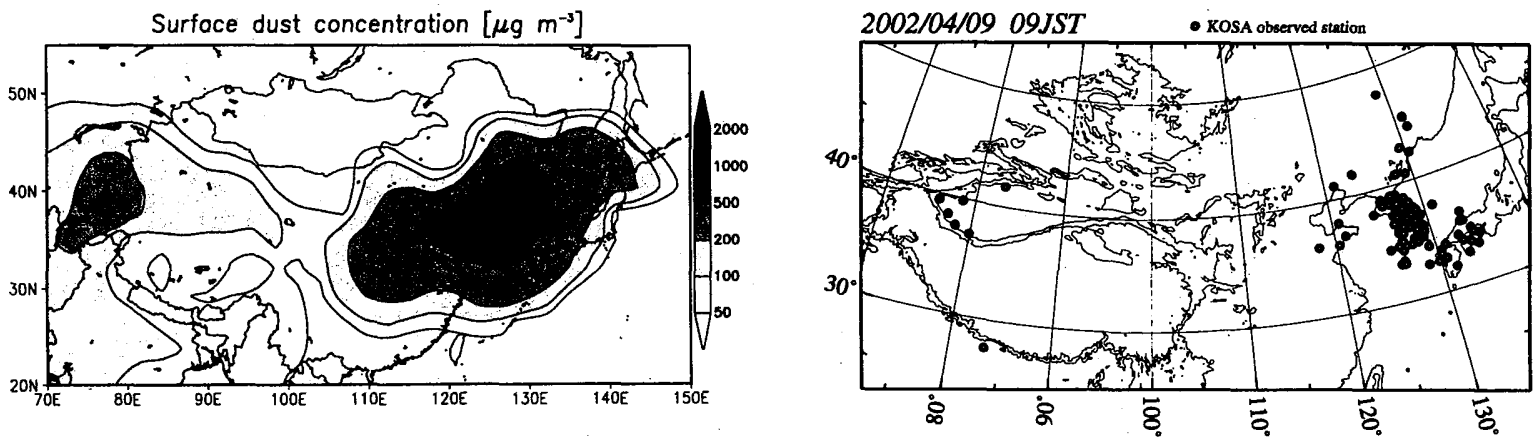

(b). 00Z April 9, 2002.
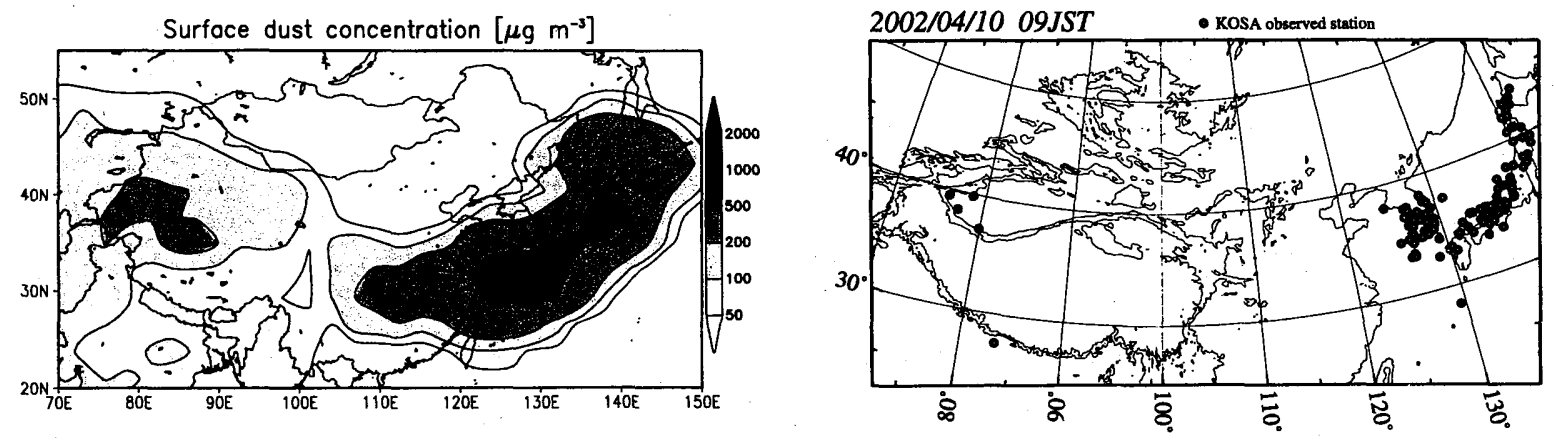

(c). $00 \mathrm{Z}$ April 10, 2002.

Figure 8. Surface distribution of mineral dust over East Asia from April 7 to April 10, 2002, compared with the distribution of stations where dust event was recorded in the SYNOP report (Y. Kurosaki, personal communication). 

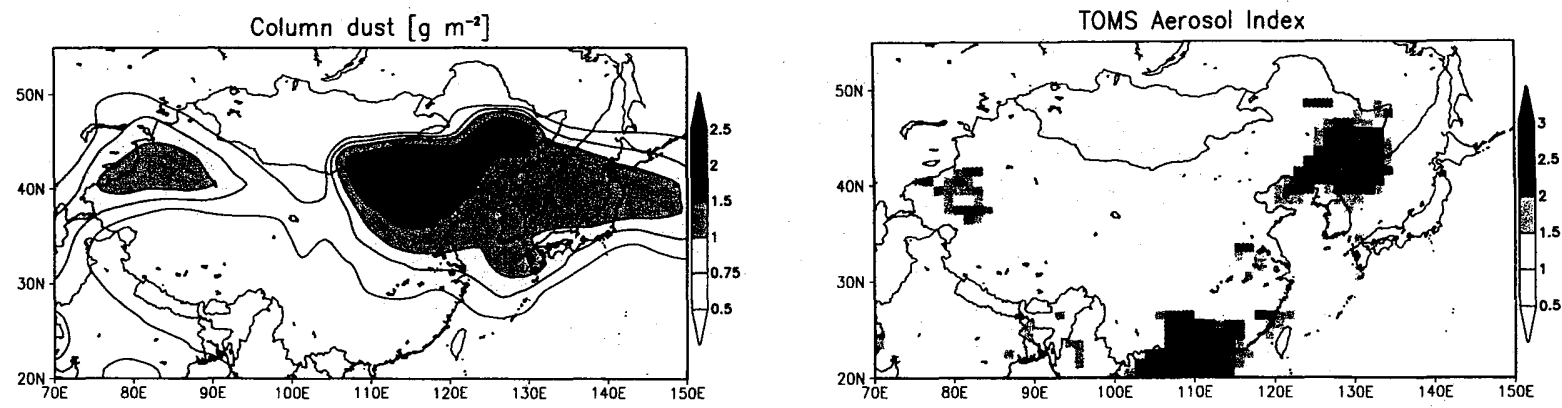

(a). 00Z April 8, 2002.
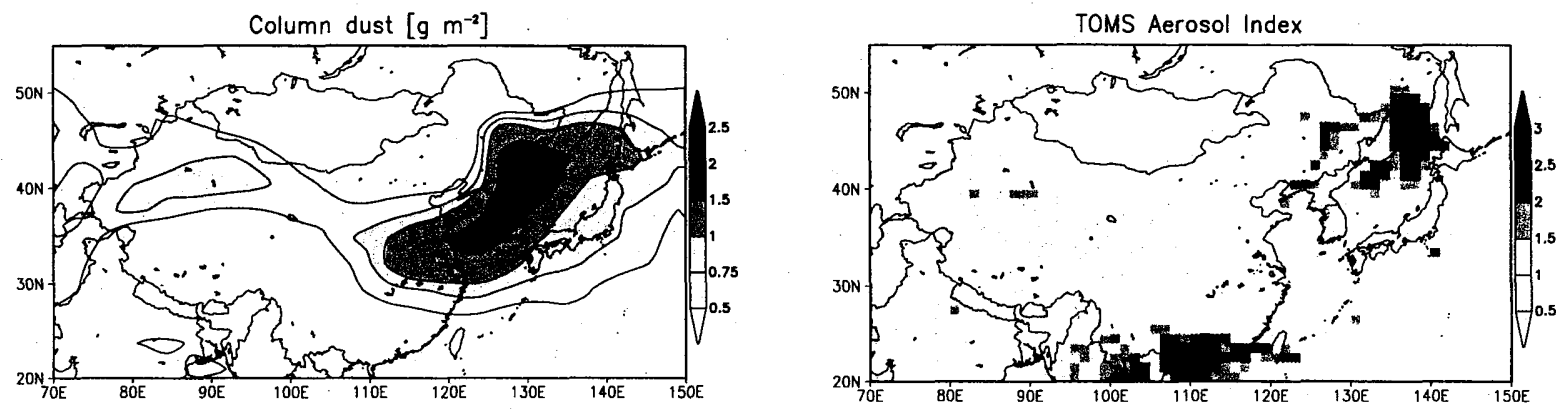

(b). 00Z April 9, 2002.
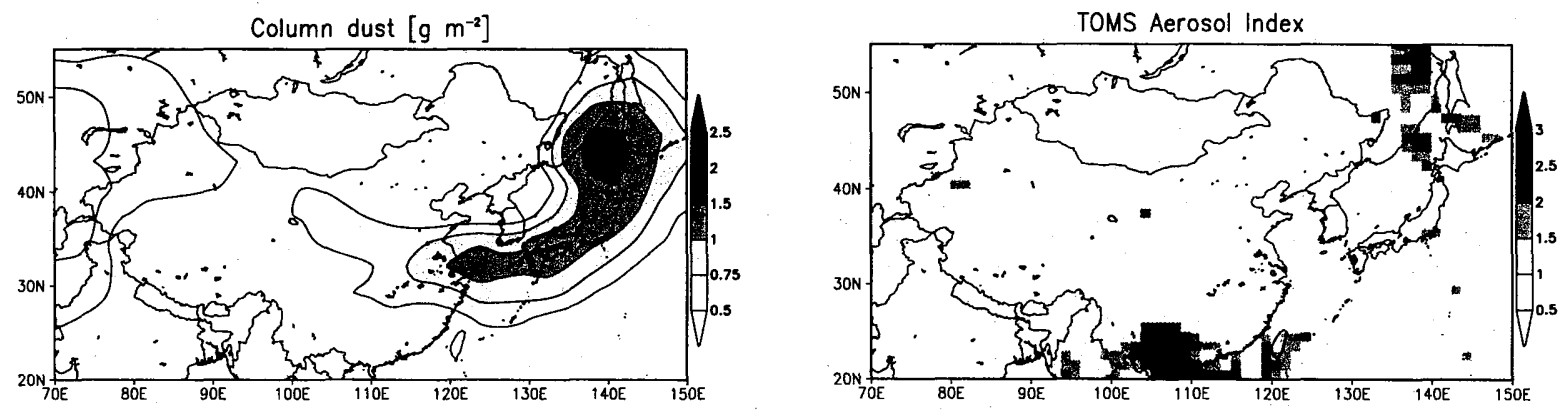

(c). $00 \mathrm{Z}$ April 10, 2002.

Figure 9. Column burden of mineral dust over East Asia from April 7 to April 10, 2002, compared with the TOMS aerosol index. 
ity of TOMS AI to the height of the dust layer (Cakmur et al., 2001), and by excluding carbonaceous aerosol from sporadic forest fires in the model. The comparisons with surface observation and TOMS AI suggest that MASINGAR can simulate the meteorological field and mineral dust distribution at a synoptic scale at a specific time fairly well with the FDDA system.

\section{Summary}

This paper introduced a new on-line global aerosol chemical transport model, MASINGAR, which provides the three-dimensional distributions of major aerosol species (sulfur compounds, carbonaceous aerosols, mineral dust aerosol, and sea -salt aerosol). It accounts for surface emissions, advective and subgrid-scale transport processes, wet and dry depositions, and chemical transformations. The model is coupled with general circulation model MRI/JMA 98. Dynamical and physical variables required by the chemical transport model are simulated on-line with the GCM with a standard time step of 20 minutes.

The model has a built-in nudging FDDA system that enables it to realistically simulate a specific period and a short-period forecast. The model simulation of mineral dust aerosol on April 2002 suggests that MASINGAR can simulate synoptic-scale aerosol events, such as outbreak and transport of dust on a day-to-day basis.

MASINGAR can be used as a base model for studying the global impact of aerosols species; studying the distributions, budgets, and interactions of aerosol species; and evaluating climatic impacts of the aerosols. We will continue to develop this model through model validation by tracer experiments, including radon 222 and its progeny, lead 210 , which are used for validation by many previous model studies (Jacob et al., 1997 ; Rasch et al., 2000) to reduce uncertainties due to the transport processes. Future model developments will include radiative process codes for evaluating radiative forcing of the aerosol species.

\section{Acknowledgments}

We are grateful to Dr. C. M. Spivakovsky for providing the distributions of $\mathrm{H}_{2} \mathrm{O}_{2}, \mathrm{OH}, \mathrm{NO}_{\mathrm{x}}$ and $\mathrm{O}_{3}$. and to the Global Emissions Inventory Activity (GEIA) for providing sulfur and carbonaceous emission inventories. We wish to thank Y. Kurosaki for productive discussions and sharing his analysis of dust aerosol, Takashi Maki of the Japan Meteorological Agency (for providing program codes of vertical eddy diffusion), and the Climate Research
Department of Meteorological Research Institute for the development of the MRI/JMA $98 \mathrm{GCM}$. Some of the figures were produced by the GFD -DENNOU Library. This study was supported by the Cooperative System for Supporting Priority Research of the Japan Science and Technology Corporation.

\section{References.}

Allen, D. J., R. B. Rood, A. M. Thompson and R. D. Hudson, 199 : Three-dimensional radon 222 calculations using assimilated meteorological data and a convective mixing algorithm. J. Geophys. Res., 101, $6871-6881$.

Andreae, M. O., 1986: The ocean as a source of atmospheric sulfur compounds. P. Buat-Menard, Ed., The Role of Air-Sea Exchange in Geochemical Cycling, Vol. C 185 of NATO ASI Series, D. Reidel Publishing Company, 331-362.

Andreae, M. O., 1990: Ocean-atmosphere interactions in the global biogeochemical sulfur cycle. Marine Chem., 30, 1-29.

Andres, R. J. and A. D. Kasgnoc, 1998: A time-averaged inventory of subaerial volcanic sulfur emissions. $J$. Geophys. Res., 103, 25251-25261.

Arakawa, A. and W. H. Schubert, 1974 : Interaction of a cumulus ensemble with the large-scale environment, part i. J. Atmos. Sci., 31, 674-701.

Atkinson, R., D. L. Baulch, R. A. Cox, R. F. Hampson, Jr., J. A. Kerr and J. Troe, 1992 : Evaluated kinetic and photochemical data for atmospheric chemistry: Supplement IV. J. Phys. Chem. Ref. Data, 21, 1125 $-1568$.

Balkanski, Y. J., D. J. Jacob, G. M. Gardner, W. C. Graustein and K. K. Turekian, 1993: Trans-port and residence times of tropospheric aerosols inferred from a global three-dimensional simulation of ${ }^{210} \mathrm{~Pb}$. J. Geophys. Res., 98, 20573-20586.

Barrie, L. A. and M. J. Barrie, 1990 : Chemical components of lower tropospheric aerosols in the high Arctic: Six years of observations. J. Atmos. Chem., 11, 211-226.

Barth, M. C., P. J. Rasch, J. T. Kiehl, C. M. Benkovitz and S. E. Schwartz, 2000: Sulfur chemistry in the National Center for Atmospheric Research Community Climate Model: Description, evaluation, features, and sensitivity to aqueous chemistry. J. Geophys. Res., 105, 1387-1415.

Benkovitz, C. M., M. T. Scholtz, J. Pacyna, L. Tarrason, J. Dignon, E. C. Voldner, P. A. Spiro, J. A. Logan and T. E. Graedel, 1996: Global gridded inventories of anthropogenic emissions of sulfur and nitrogen. $J$. Geophys. Res., 101, 29239-29253.

Bey, I., D. J. Jacob, R. M. Yantosca, J. A. Logan, B. D. Field, A. M. Fiore, Q. Li, H. Y. Liu, L. J. Mickley and M. G. Schultz, 2001 : Global modeling of tropos- 
pheric chemistry with assimilated meteorology Model description and evaluation. J. Geophys. Res., 106, 23073-23096.

Brasseur, G. P., D. A. Hauglustaine, S. Walters, P. J. Rasch, J.-F. Muller, C. Granier and X. X. Tie, 1998: MOZART, a global chemical transport model for ozone and related chemical tracers 1 . model description. J. Geophys. Res., 103, 28265-28289.

Brasseur, G. P., J. J. Orlando and G. S. Tyndall, Eds., 1999: Atmospheric Chemistry and Global Climate. Oxford University Press, p.438-440.

Cakmur, R. V., R. L. Miller and I. Tegen, 2001: A comparison of seasonal and interannual variability of soil dust aerosols over the Atlantic Ocean as inferred by the TOMS AI and AVHRR AOT retrievals. J. Geophys. Res., 106, 18287-18303.

Charlson, R. J., J. Langner, H. Rodhe, C. B. Leovy and S. G. Warren, 1991: Perturbation of the northern hemisphere radiative balance by backscattering from anthropogenic sulfate aerosols. Tellus, 43AB, 152-163.

Charlson, R. J., S. E. Schwartz, J. M. Hales, R. D. Cess, J. A. Coakley, Jr., J. E. Hansen and D. J. Hofmann, 1992 : Climate forcing by anthropogenic aerosols. Science, 255, 423-430.

Chatfield, R. B. and P. J. Crutzen, 1984 : Sulfur dioxide in remote oceanic air: Cloud transport of reactive precursors. J. Geophys. Res., 89, 7111-7132.

Chin, M., R. B. Rood, S.-J. Lin, J.-F. Muller and A. Thompson, 2000 : Atmospheric sulfur cycle simulated in the global model GOCART: Model description and global properties. J. Geo-phys. Res., 105, 24671-24687.

Chin, M., P. Ginoux, S. Kinne, O. Torres, B. N. Holben, B. N. Duncan, R. V. Martin, J. A. Logan, A. Higurashi and T. Nakajima, 2002: Tropospheric aerosol optical thickness from the GOCART model and comparisons with satellite and sun photometer measurements. J. Atmos. Sci., 59, 461-483.

Cohan, D. S., M. G. Schultz, D. J. Jacob, B. G. Heikes and D. R. Blake, 1999 : Convective injection and photochemical decay of peroxides in the tropical upper troposphere: Methyl iodide as a tracer of marine convection. J. Geophys. Res., 104, 5717-5724.

Cooke, W. F. and J. J. N. Wilson, 1996: A global black carbon aerosol model. J. Geophys. Res., 101, 19395 -19409 .

Cooke, W. F., C. Liousse, H. Cachier and J. Feichter, 1999 : Construction of a $1^{\circ} \times 1^{\circ}$ fossil fuel emission data set for carbonaceous aerosol and implementation and radiative impact in the ECHAM4 model. $J$. Geophys. Res., 104, 22137-22162.

Costen, R. C., G. M. Tennille and J. S. Levine, 1988: Cloud pumping in a one-dimensional photochemical model. J. Geophys. Res., 93, 15941-15954.

DeFries, R. S. and J. R. G. Townshend, 1994 : NDVI -derived land cover classification at a global scale. Int. J. Remote Sensing, 15, 3567-3586.
DeMore, W. B., S. P. Sander, D. M. Golden, R. F. Hampson, M. J. Kurylo, C. J. Howard, A. R. Ravishankara, C. E. Kolb and M. J. Molina, 1997 : Chemical kinetics and photochemical data for use in stratospheric modeling, Evaluation Number 12. Pasadena, California, JPL Publication 97-4.

Feichter, J., E. Kjellstrom, H. Rodhe, F. Dentener, J. Lelieveld and G.-J. Roelofs, 1996 : Simulation of the tropospheric sulfur cycle in a global climate model. Atmos. Environ., 30, 1693-1707.

Gidel, L. T., 1983 : Cumulus cloud transport of transient tracers. J. Geophys. Res., 88, 6587-6599.

Gillette, D., 1978: A wind tunnel simulation of the erosion of soil: Effect of soil texture, sandblasting, wind speed, and soil consolidation on dust production. Atmos. Environ., 12, 1735-1743.

Giorgi, F. and W. L. Chameides, 1986 : Rainout lifetimes of highly soluble aerosols and gases as inferred from simulations with a general circulation model. $J$. Geophys. Res., 91, 14367-14376.

Gong, S. L., L. A. Barrie and J.-P. Blanchet, 1997 : Modeling sea-salt aerosols in the atmosphere 1 . model development. J. Geophys. Res., 102, 3805-3818.

Guenther, A., C. N. Hewitt, D. Erickson, R. Fall, C. Geron, T. Graedel, P. Harley, L. Klinger, M. Lerdau, W. A. McKay, T. Pierce, B. Scholes, R. Steinbrecher, R. Tallamraju, J. Taylor and P. Zimmerman, 1995: A global model of natural volatile organic compound emissions. J. Geophys. Res., 100, 8873 -8892 .

Herman, J. R., P. K. Bhartia, O. Torres, C. Hsu, C. Seftor and E. Celarier, 1997: Global distribution of UV -absorbing aerosols from Nimbus 7/TOMS data. J. Geophys. Res., 102, 16911-16922.

Hynes, A. J., P. H. Wine and J. M. Nicovich, 1988: Kinetics and mechanism of the reactions of $\mathrm{OH}$ with $\mathrm{CS}_{2}$ under atmospheric conditions. J. Phys. Chem, 92, 3486-3852.

Ikegami, M., K. Okada, Y. Zaizen and Y. Makino, 1994 : Sea-salt particles in the upper tropical troposphere. Tellus, 46B, 142-151.

Intergovermental Panel on Climate Change (IPCC), 2001: Climate change 2001: The Scientific Basis. Cambridge University Press.

Jacob, D. J., M. J. Prather, P. J. Rasch, R.-L. Shia, Y. J. Balkanski, S. R. Beagley, D. J. Bergmann, W. T. Blackshear, M. Brown, M. Chiba, M. P. Chipperfield, J. de Grandpre, J. E. Dignon, J. Feichter, C. Genthon, W. L. Grose, P. S. Kasibhatla, I. Kohler, M. A. Kritz, K. Law, J. E. Penner, M. Ramonet, C. E. Reeves, D. A. Rotman, D. Z. Stockwell, P. F. J. V. Velthoven, G. Verver, O. Wild, H. Yang and P. Zimmerman, 1997 : Evaluation and intercomparison of global atmospheric transport models using ${ }^{222} \mathrm{Rn}$ and other short-lived tracers. J. Geophys. Res., 102, 5953-5970.

Jacobson, M. Z., 1999: Fundamentals of Atmospheric Modeling. Cambridge University Press, p203-226. 
Kalnay, E., M. Kanamitsu, R. Kistler, W. Collins, D. Deaven, L. Gandin, M. Iredell, S. Saha, G. White, J. Woollen, Y. Zhu, M. Chelliah, W. Ebisuzaki, W. Higgins, J. Janowiak, K. C. Mo, C. Ropelewski, J. Wang, A. Leetmaa, R. Reynolds, R. Jenne and D. Joseph, 1996: The NCEP/NCAR 40-year reanalysis project. Bull. Amer. Meteor. Soc., 77, 437 -471 .

Kettle, A. J., M. O. Andreae, D. Amouroux, T. W. Andreae, T. S. Bates, H. Berresheim, H. Binge-mer, R. Boniforti, M. A. J. Curran, G. R. DiTullio, G. Helas, G. B. Jones, M. D. Keller, R. P. Kiene, C. Leck, M. Levasseur, G. Malin, M. Maspero, P. Matrai, A. R. McTaggart, N. Mihalopoulos, B. C. Nguyen, A. Novo, J. P. Putaud and S. Rapsomanikis, 1999: A global database of sea surface dimethylsulfide (DMS) measurements and a procedure to predict sea surface DMS as a function of latitude, longitude and month. Global Biogeochem. Cycles, 13, 399-444.

Khalil, M. A. K. and R. A. Rasmussen, 1984: Global sources, lifetimes and mass balances of carbonyl sulfide (OCS) and carbon disulfide $\left(\mathrm{CS}_{2}\right)$ in the Earth's atmosphere. Atmos. Environ., 18, 1805-1813.

Koch, D., D. Jacob, I. Tegen, D. Rind and M. Chin, 1999 : Tropospheric sulfur simulation and sulfate direct radiative forcing in the Goddard Institute for Space Studies general circulation model. J. Geophys. Res., 104, 23799-23822.

Koga, S., 1993: Chemical reactions of dimethylsulfide in the marine atmosphere. $\mathrm{PhD}$ thesis, Nagoya University.

Kurosaki, Y. and M. Mikami, 2002: Seasonal and regional characteristics of dust event in the Taklimakan Desert. J. Arid Land Studies, 11, 245-252.

Langner, J. and H. Rodhe, 1991: A global three-dimensional model of the tropospheric sulfur cycle. $J$. Atmos. Chem., 13, 225-263.

Liousse, C., J. E. Penner, C. Chuang, J. J. Walton, H. Eddleman and H. Cachier, 1996: A global three -dimensional model study of carbonaceous aerosols. J. Geophys. Res., 101, 19411-19432.

Liss, P. S. and L. Merlivat, 1986: Air-sea exchange rates: ntroduction and synthesis. P. BuatMenard, Ed., The Role of Air-Sea Exchange in Geochemical Cycling, Vol. C 185 of NATO ASI Series, D. Reidel Publishing Company, 113-127.

Lohmann, U., K. von Salzen, N. McFarlane, H. G. Leighton and J. Feichter, 1999: Tropospheric sulfur cycle in the Canadian general circulation model. $J$. Geophys. Res., 104, 26833-26858.

Louis, J.-F., 1979: A parametric model of vertical eddy fluxes in the atmosphere. Bound. Layer Meteor., 17, 187-202.

Mahowald, N. M., P. J. Rasch and R. G. Prinn, 1995 : Cumulus parameterizations in chemical transport models. J. Geophys. Res., 100, 26173-26189.

Mellor, G. L. and T. Yamada, 1974: A hierarchy of turbulence closure models for planetary boundary layers. J. Atmos. Sci., 31, 1791-1806.

Mikami, M., O. Abe, M. Du, O. Chiba, K. Fujita, M. Hayashi, Y. Iwasaka, K. Kai, K. Masuda, T. Nagai, T. Ootomo, J. Suzuki, A. Uchiyama, S. Yabuki, Y. Yamada, M. Yasui, G. Shi, X. Zhang, Z. Shen, W. Wei and J. Zhou, 2002: The impact of aeolian dust on climate: Sino-Japanese cooperative project ADEC. J. Arid Land Studies, 11, 211-222.

Monahan, E. C., D. E. Spiel and K. L. Davidson, 1986 : A model of marine aerosol generation via whitecaps and wave disruption. E. C. Monahan and G. M. Niocaill, Eds., Oceanic Whitecaps, D. Reidel, 167 -174 .

Muller, J.-F. and G. Brasseur, 1995 : IMAGES : A three -dimensional chemical transport model of the global troposphere. J. Geophys. Res., 100, 16445 -16490 .

Olivier, J. G. J. and J. J. M. Berdowski, 2001 : Global emissions sources and sinks. J. Berdowski, R. Guicherit and B. J. Heij, Eds., The Climate System, A.A. Balkema Publishers/Swets \& Zeitlinger Publishers, Lisse, The Netherlands, 33-78.

Olivier, J. G. J., J. J. M. Berdowski, J. A. H. W. Peters, J. Bakker and A. J. H. V. en J.-P.J. Bloos, 2001 : Applications of EDGAR. Including a description of EDGAR 3.0: reference database with trend data for 1970-1995.RIVM, Bilthoven. RIVM report no. 773301 001/ NOP report no. 410200051.

Penner, J. E., C. C. Chuang and K. Grant, 1998 : Climate forcing by carbonaceous and sulfate aerosols. Clim. Dyn., 14, 849-851.

Pham, M., J.-F. Muller, G. P. Brasseur, C. Granier and G. Megie, 1995: A three-dimensional study of the tropospheric sulfur cycle. J. Geophys. Res., 100, 26061 -26092 .

Prather, M., M. McElroy, S. Wofsy, G. Russell and D. Rind, 1987: Chemistry of the global troposphere: Fluorocarbons as tracers of air motion. J. Geophys. Res., 92, 6579-6613.

Rasch, P. J., M. C. Barth, J. T. Kiehl, S. E. Schwartz and C. M. Benkovitz, 2000: A description of the global sulfur cycle and its controlling processes in the National Center for Atmospheric Research Community Climate Model, Version 3. J. Geophys. Res., 105, 1367-1385.

Roelofs, G.-J., J. Lelieveld and L. Ganzeveld, 1998 : Simulation of global sulfate distribution and the influence on effective cloud drop radii with a coupled photochemistry-sulfur cycle model. Tellus, 50B, 224-242.

Saltzman, E. S., D. B. King, K. Holmen and C. Leck, 1993: Experimental determination of the diffusion coefficient of dimethylsulfide in water. $J$. Geophys. Res., 98, 16481-16486.

Seinfeld, J. H. and S. N. Pandis, 1997: Atmospheric chemistry and physics: From air pollution to cli mate change. A Wiely-Interscience publication, p. 
958-996, p337-407.

Shao, Y., 2001: A model for mineral dust emission. $J$. Geophys. Res., 106, 20239-20254.

Shibata, K., H. Yoshimura, M. Ohizumi, M. Hosaka and M. Sugi, 1999: A simulation of tropo-sphere, stratosphere and mesosphere with an MRI/JMA98 GCM. Pap. Meteor. Geophys., 50, 15-53.

Sokolik, I. N., O. B. Toon and R. W. Bergstrom, 1998 : Modeling the radiative characteristics of airborne mineral aerosols at infrared wavelengths. $J$. Geophys. Res., 103, 8813-8826.

Spiro, P. A., D. J. Jacob and J. A. Logan, 1992: Global inventory of sulfur emissions with $1^{\circ} \times 1^{\circ}$ resolution. J. Geophys. Res., 97, 6023-6036.

Spivakovsky, C. M., J. A. Logan, S. A. Montzka, Y. J. Balkanski, M. Foreman-Fowler, D. B. A. Jones, L. W. Horowitz, A. C. Fusco, C. A. M. Brenninkmeijer, S. C. Wofsy and M. B. McEl-roy, 2000 : hree-dimensional climatological distribution of tropospheric $\mathrm{OH}$ : Update and evaluation. J. Geophys. Res., 105, 8931-8980.

Staniforth, A. and J. Cote, 1991 : Semi-Lagrangian integration schemes for atmospheric models - a review. Mon. Wea. Rev., 119, 2206-2223.

Takemura, T., H. Okamoto, Y. Murayama, A. Numaguti, A. Higurashi and T. Nakajima, 2000: Global three-dimensional simulation of aerosol optical thickness distribution of various origins. J. Geophys. Res., 105, 17853-17873.

Tegen, I. and I. Fung, 1994 : Modeling of mineral dust in the atmosphere: Sources, transport, and optical thickness. J. Geophys. Res., 99, 22897-22914.

Tegen, I., A. A. Lacis and I. Fung, 1996: The influence on climate forcing of mineral aerosols from disturbed soils. Nature, 380, 419-422.

Twomey, S., 1974 : Pollution and the planetary albedo. Atmos. Environ., 8, 1251-1256.

Voldner, E. C., Y.-F. Li, M. T. Scholtz and K. Davidson, manuscript in preparation, 1996: $1^{\circ} \times 1^{\circ}$ global $\mathrm{SO}_{x}$ and $\mathrm{NO}_{x} 2$-level inventoriy resolved seasonally into emission sectors and point and area emission sources. http://www.ortech.ca/cgeic/poster.html.

Wanninkhof, R., 1992 : Relationship between wind speed and gas exchange over the ocean. J. Geophys. Res., 97, 7373-7382.

Warneck, P., 1999: Chemistry of the Natural Atmosphere. Vol. 71 of International Geophysics Series, Academic Press, 2 edition, p.614.

Wesely, M. L., 1989 : Parameterization of surface resistances to gaseous dry deposition in regional-scale numerical models. Atmos. Environ., 23, 1293-1304.

Woodward, S., 2001: Modeling the atmospheric life cycle and radiative impact of mineral dust in the Hadley Centre climate model. J. Geophys. Res., 106, 18155-18166.

World Meteorological Organization, 1974: Manual on Codes. Vol. 1, WMO Publ., 306.

Yin, F., D. Grosjean and J. H. Seinfeld, 1990 : Photooxidation of dimethyl sulfide and dimethyl disulfide. I : Mechanism development. J. Atmos. Chem., 11, 309 -364 .

Zimmermann, P. H., 1987: MOGUNTIA: A handy global tracer model. Proceedings of the 16th NATO/CCMS International Technical Meeting on Air pollution modeling and its application, 593-608.

\title{
大気大循環モデル MRI/JMA 98 と結合した全球対流圏エーロゾル化学輸送モデル MASINGAR：モデルの解説
}

\author{
田中泰宙、折戸光太郎（気象研究所／重点研究支援協力員） \\ 関山 剛、柴田清孝、千葉 長（気象研究所） \\ 田中 浩 (名古屋大学大学院環境学研究科)
}

大気エーロゾルとその関連物質の分布の研究のために新たに開発された 3 次元エーロゾル化学輸送モデル Model of Aerosol Species IN the Global AtmospheRe (MASINGAR)の詳細を記す。MASINGAR は大気大循環モデル MRI/JMA 98 と結合されたオンライン・モデルである。MASINGAR は非海塩起源硫酸塩、炭素系、鉱物ダスト、海塩起源のエーロ ゾルを含み、移流、サブグリッドスケールの渦拡散と対流による輸送、地表面からの物質の放出、乾性・湿性沈着、化学 反応を扱う。移流はセミ・ラグランジュ法によって計算される。積雲対流による鉛直輸送は荒川・シューバート法の積雲 対流マスフラックスを基にしてパラメタライズされている。モデルの空間・時間解像度は可変であり、T $42\left(2.8^{\circ} \times 2.8^{\circ}\right)$, 鉛直 30 層 $(0.8 \mathrm{hPa}$ まで)、で時間刻み 20 分での積分が標準的に扱われている。さらに、モデルは同化気象場データを用 いるナッジング手法による 4 次元同化システムを内蔵し、これによって特定の期間の現実的なシミュレーションやエーロ ゾルの短期間の予報が可能となっている。2002 年 4 月の鉱物ダストエーロゾルのシミュレーションから、MASINGAR に よって総観規模のエーロゾルのイベントが良くシミュレートできることが示唆されている。 